\section{Journal of Home \\ Economics}

http://homeEcon.menofia.edu.eg

\author{
مجلة الاقتصاد المنزلي

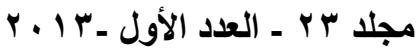

ISSN 1110-2578

\title{
تصور مقترح لتقييم أداء عضو هيئة التدريس بالجامعات المصرية في ضوء الاتجاهات العالمية المعاصرة
}

محمه المصيلحي حمح إبرا هيم،لمياء شوقت على أحمد،مها حمح عبد الخالق الامس

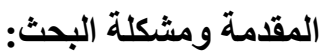

تعد الجامعات مركز إثعاع حضاري لأبي مجتمع من المجتمعات، فهي واجهة الدول

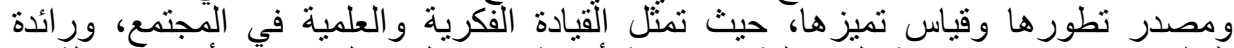

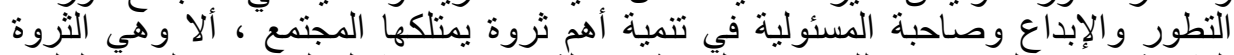

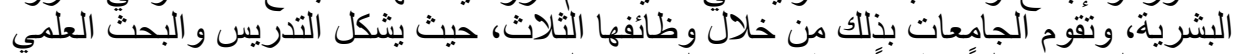

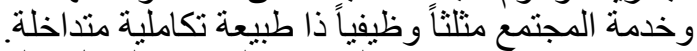

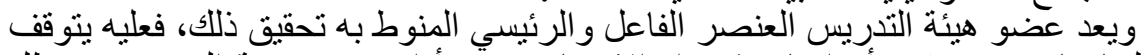

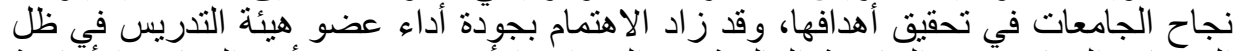

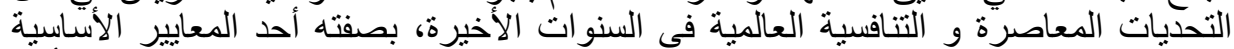

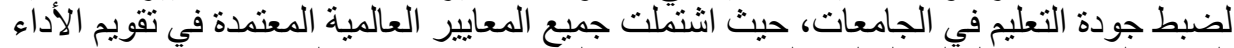

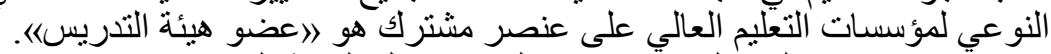

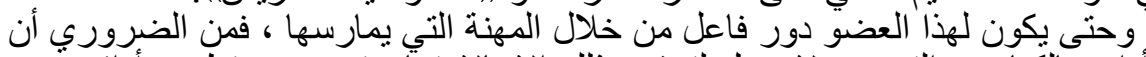

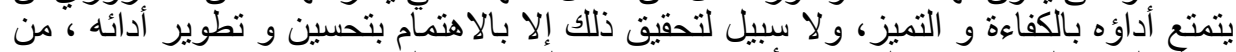

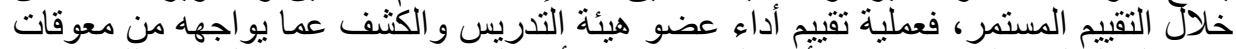

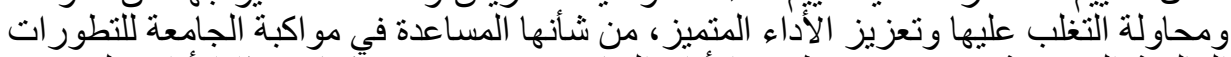

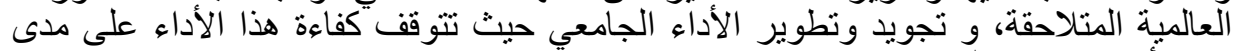
كفاءة أعضاء هيئة التدريس.

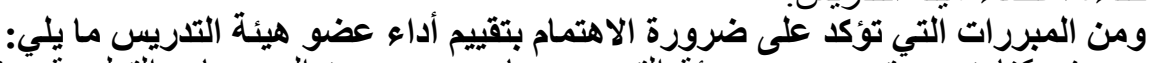

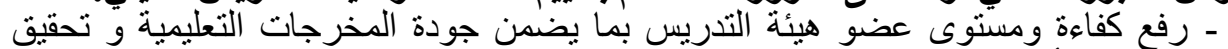
التمبيز الأكاديمي.

- إعطاء عضو هيئية التدريس الفرصة لتنمية وتحسين وتطوير مهاراته المتعلقة بأصول

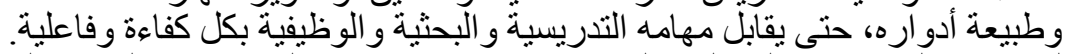

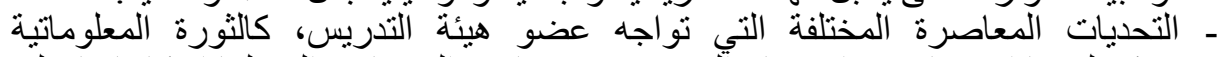

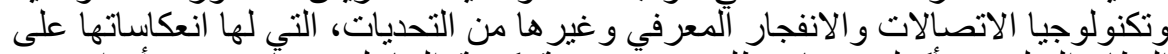

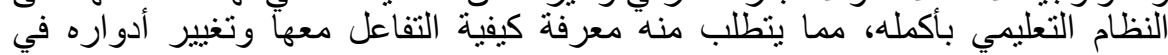
ضونُها. ـ تطلعات الوصول إلى الجودة الثشاملة في التعليم، والحصول على المعلى الاعتماد الأكاديمي

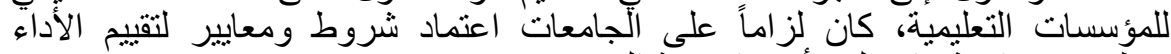

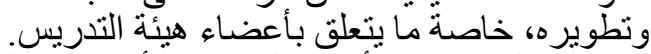

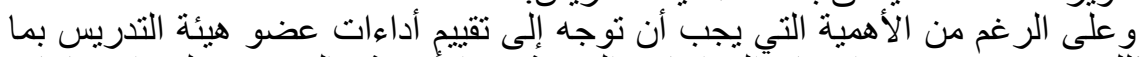
يمثله ذلك من ضرورة، واهتمام "الدراسات العربية و الإنى الإنبية بالوقوف على الاتجاهات 


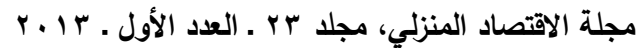

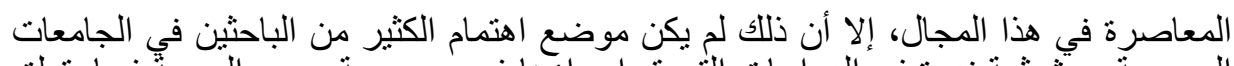

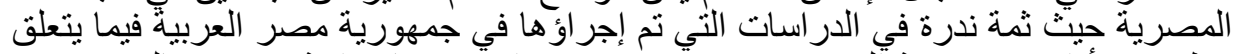

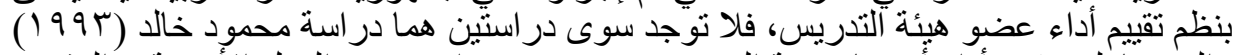

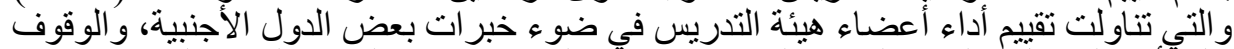

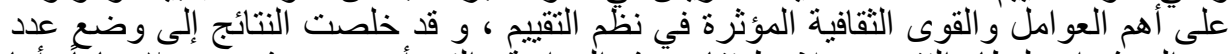

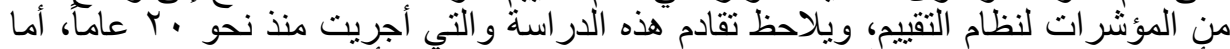

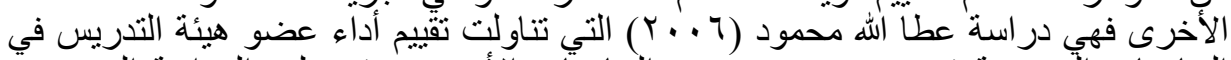

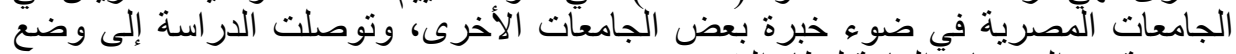

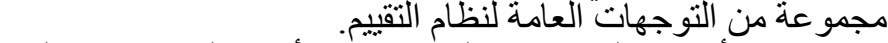

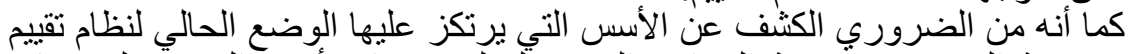

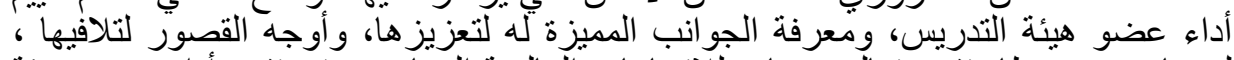

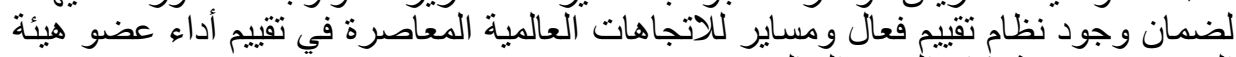

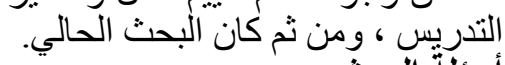

يحاول البحث الإجابة عن التساؤ لات التالية:

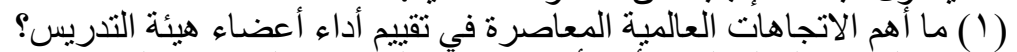

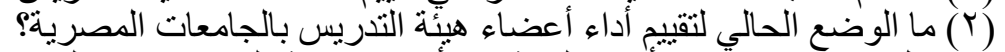

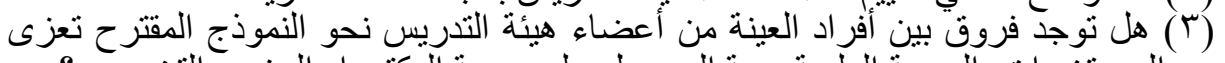

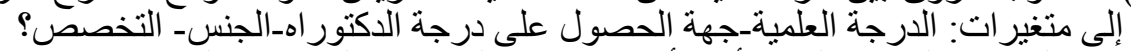

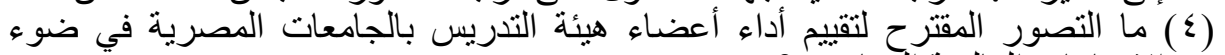

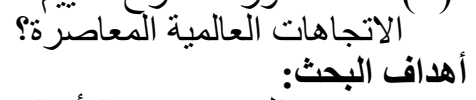

يستهذف البحث تحقيق الأهداف التالية:

ـ ـ الكثف عن أهم الاتجاهات العالمية المعاصرة لتقبيم أداء عضو هيئة التدريس بالجامعات المختلفة.

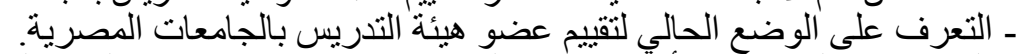

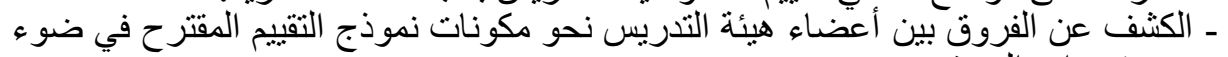

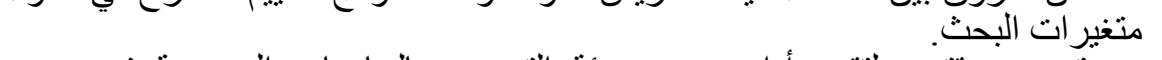
- وضع تصور مقترح لتقييم أداء عضو هيئة التدريس بالجامعات المصرية في ضوء الآتجاهات العالمينة المعأصرة.

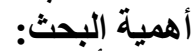

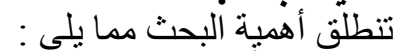

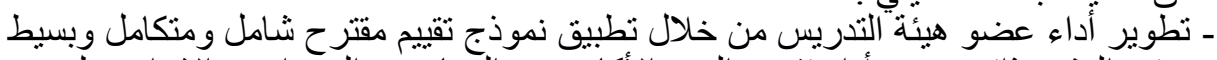

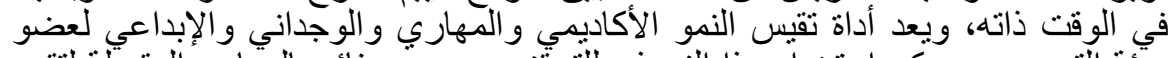

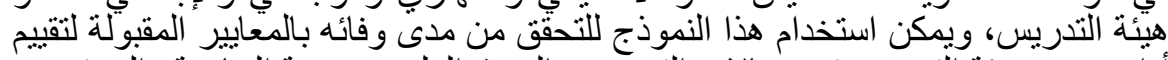

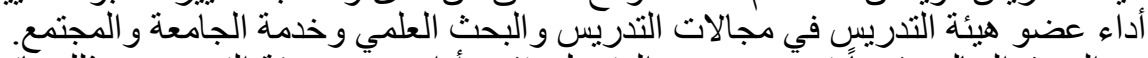

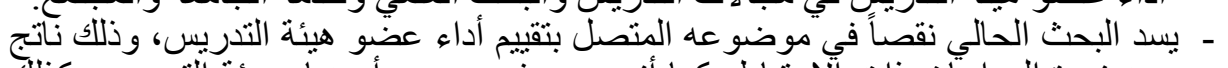

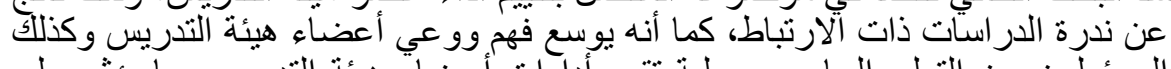

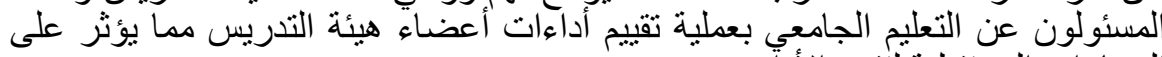

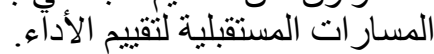

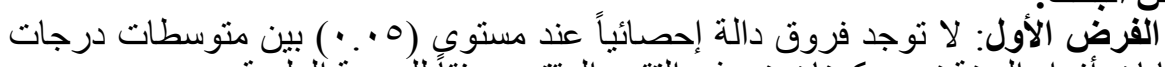

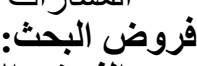
استجابات أفر اد العينة نحو مكونات نموذج التقونييم المقتر ح وفقاً للدرجة العلمية. 


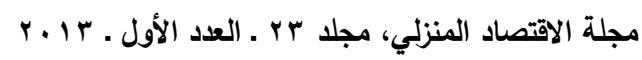

الفرض الثاني: لا توجد فروق دالة إحصائياً عند مستوى (0 . . • ) بين منوسطات درجات

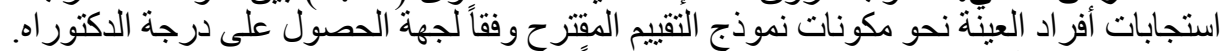

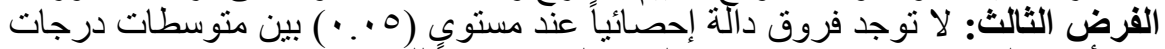

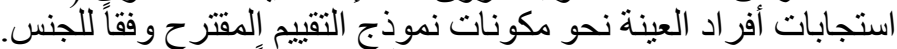

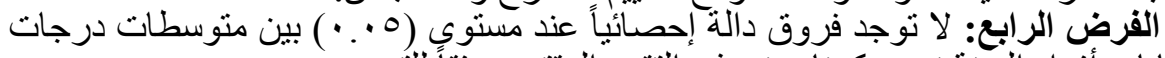

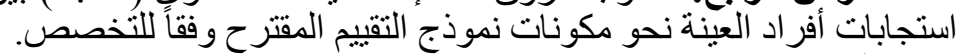

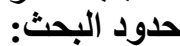

يقتصر البحث على الحدود التالية:

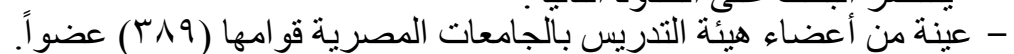

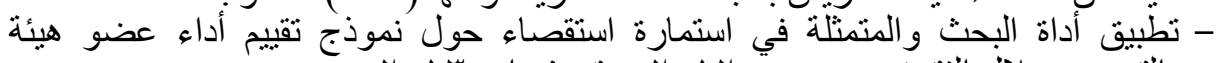

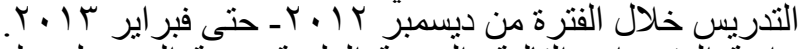

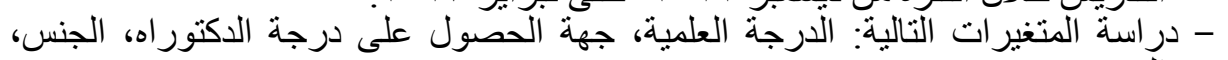

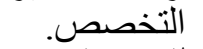
مصطلحات البحث:

تتمثل مصطلح التحات البحث فيما يلي:-

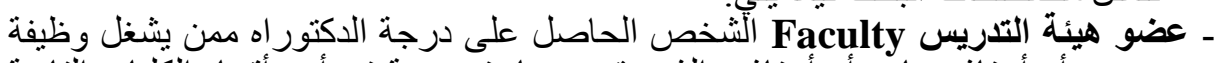

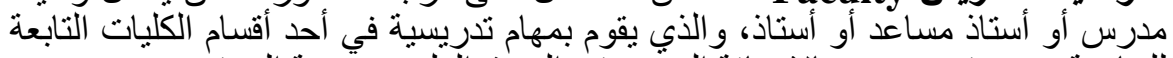

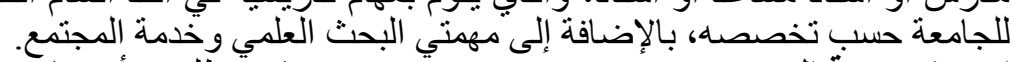

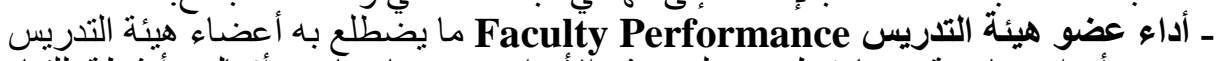

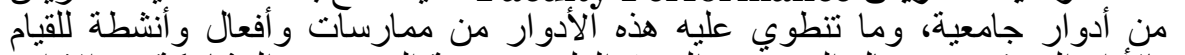

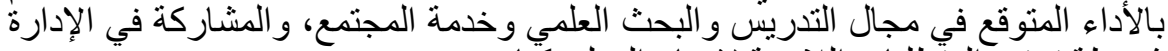

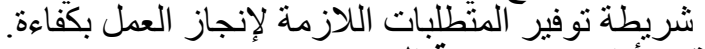

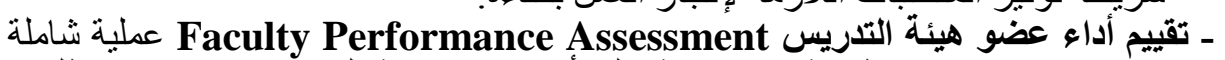

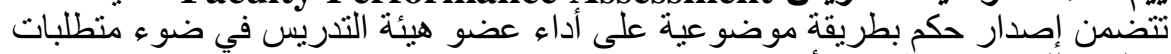

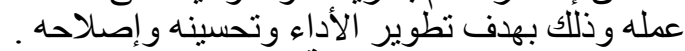
الإطار النظري والاراسات السابقة

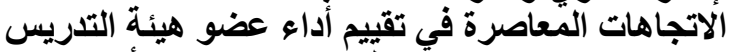

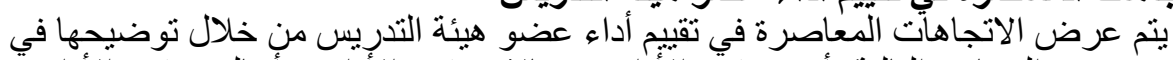

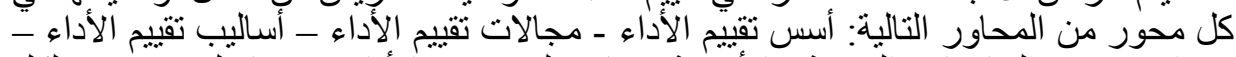

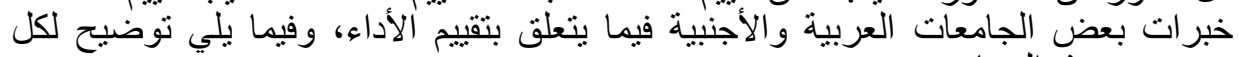

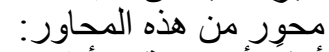

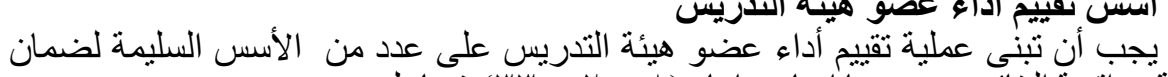

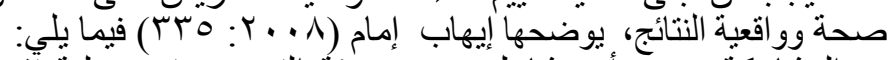

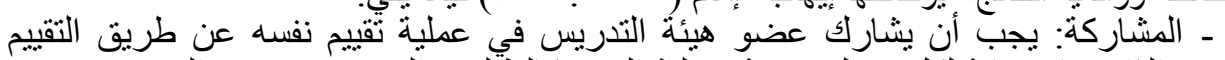

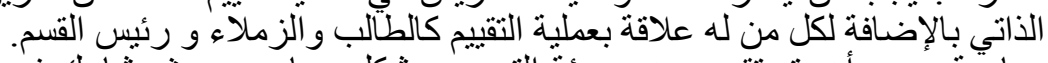

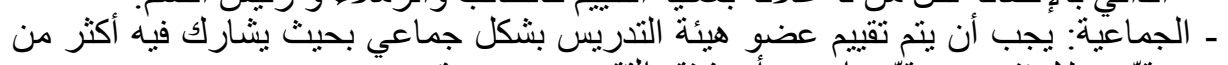

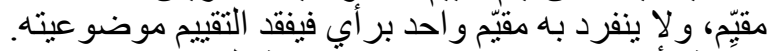

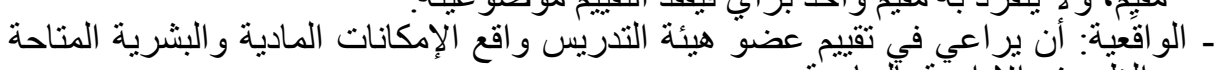
و الظروف الإنداريّة بآلجامعة.

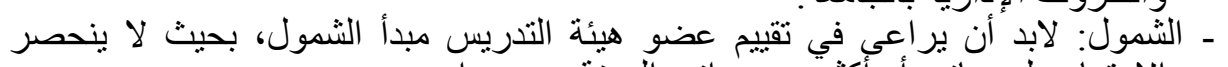

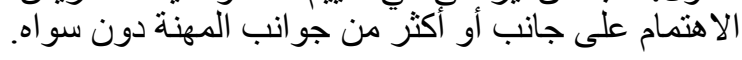




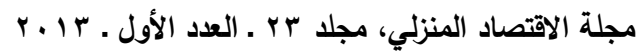

ـ الاستمر ارٍ: ألاًّ تتقيد عملية التقييم بفترة معينة تتوقف أو تنتهي بعدها، ويجب أن يكون التقييم

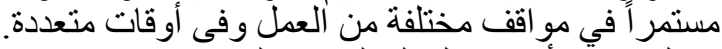

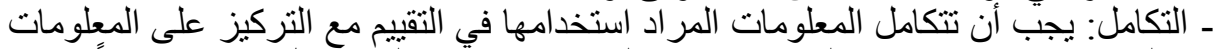

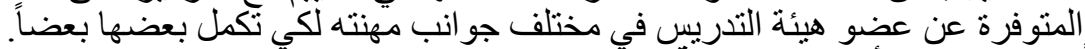
ثانياً: مجالات تقييم أداء عضو هينة هيئة التذريس

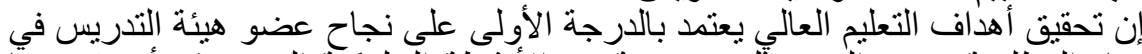

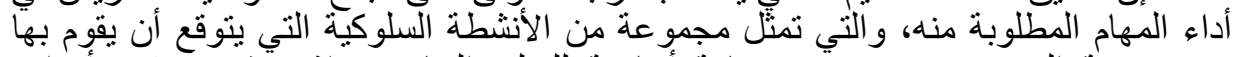

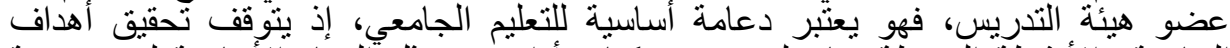

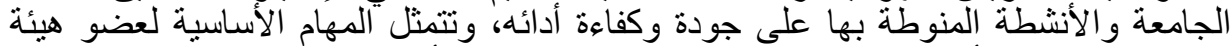
التدريس في ثلاث أنشطة رئيسية والتي ينم بناء عليها تقييم أدائه فيها، و المتمثلة في التدريس و البحث العلّمي وخدمة الجامعة و المجنمع.

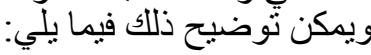

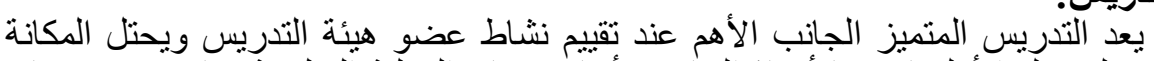

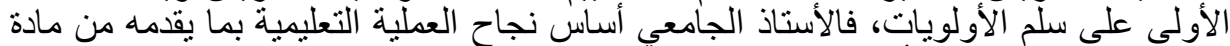

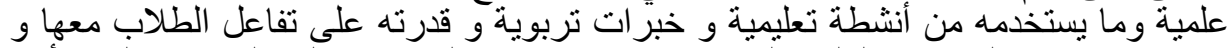

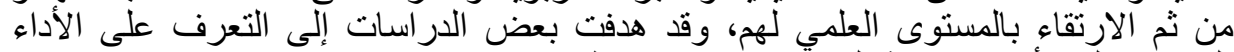

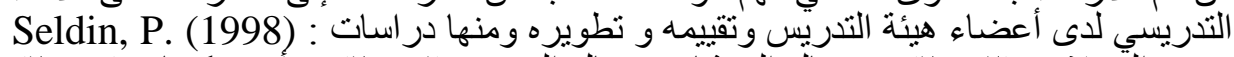

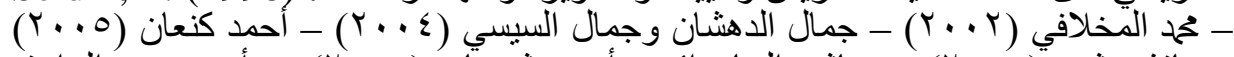

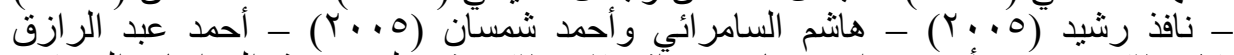

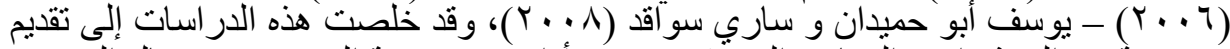

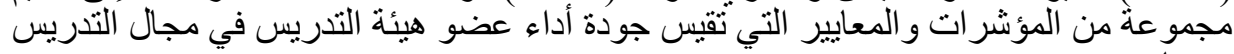

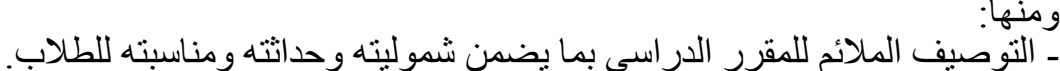

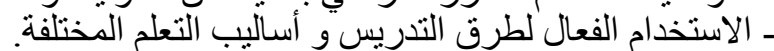

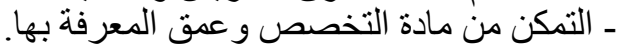
ـ ـ عرض المادة العلمية بطريقة جذابة مشوقة الفئة تثير التفكير.

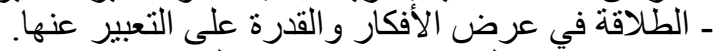

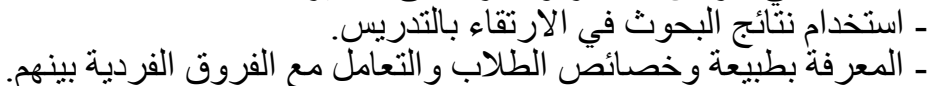

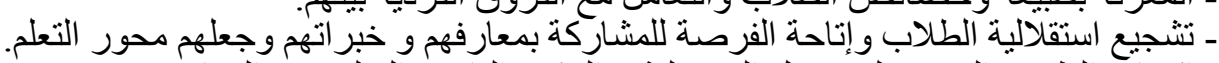

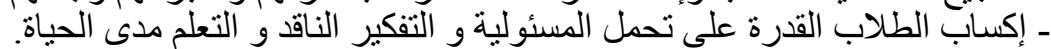

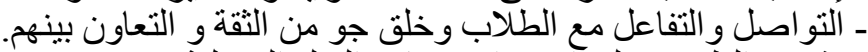
ـ ـتشيع الطلاب على أستخدام مصادر التعلم المختلفئ.

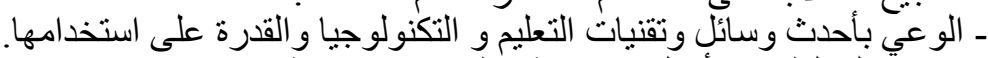

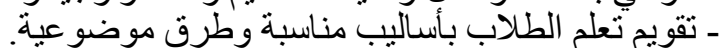

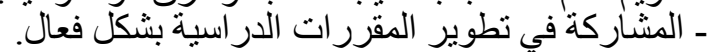

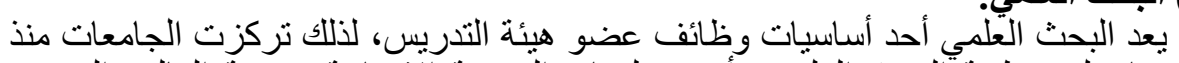
(ب) البحث العلمي: تأسيسها على وظيفة "البحث العلمي وألمي وأهميته لزيادة المعرفة الإنسانية وخدمة العالم و المجتمع المحلي وحل قضائاه ومشكلاته.

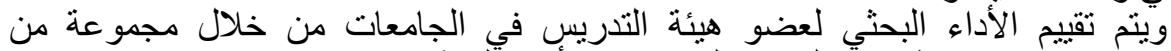

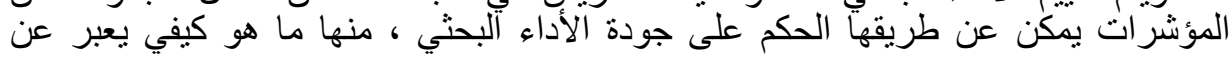




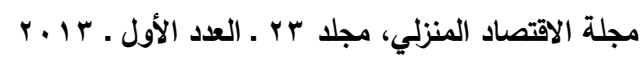

الجودة و النوعية ومنها ما هو كمي يعبر عن العدد و الكمية، يوضحها كل من ضياء الدين

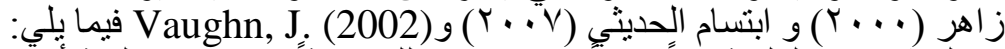

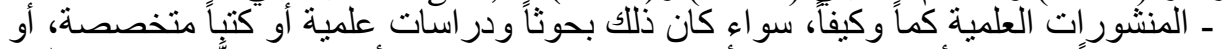

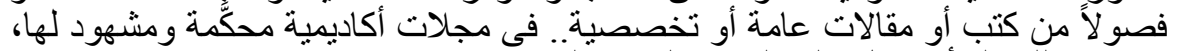

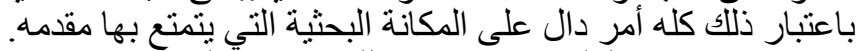

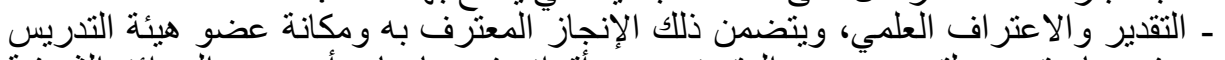

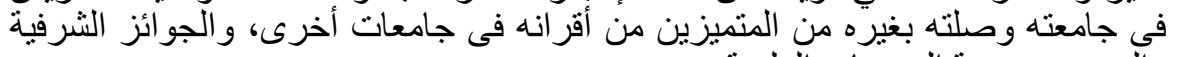
و المنح و عضوية الجمعيات العلمية.

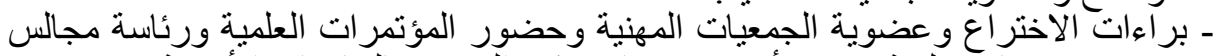

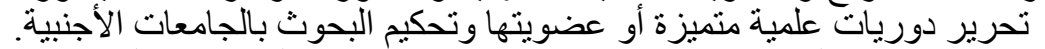

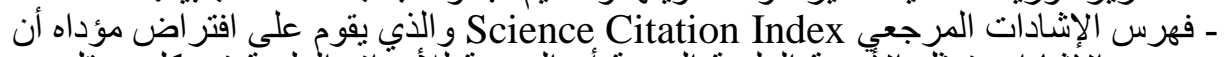

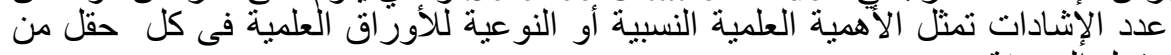
حقول ألمعرفة.

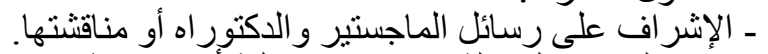

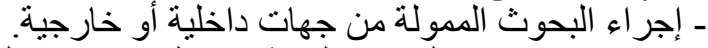

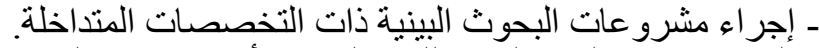
ـ ألمشاركة فى حلقات البحثث للنمو المهني لأعضاء البهاء هيئة التدريس.

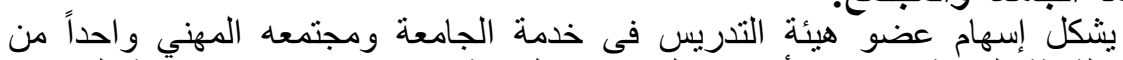

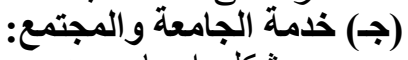

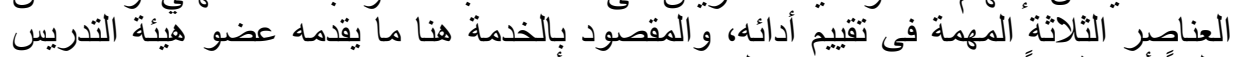

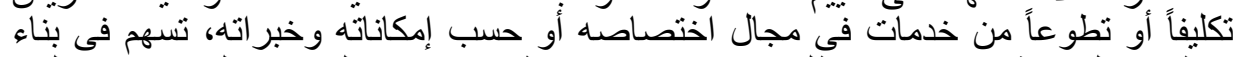

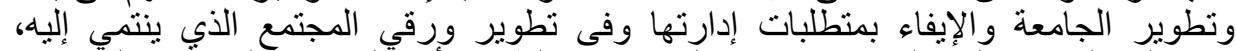

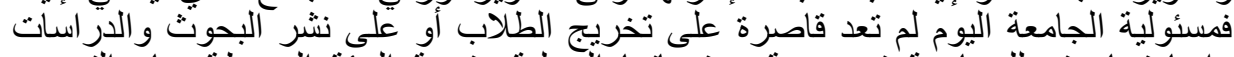

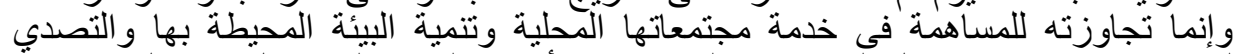

لمشكلاتها والإسهام في حل المعضلات التي تو اجه الأجهزة المدنية التي تعمل وتلتعامل معها.

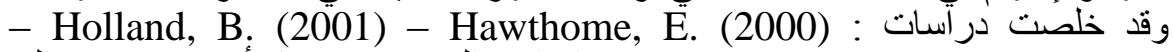

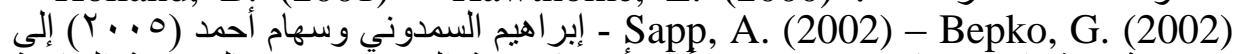
مجموعة مؤشرات ومعايير تقيس جودة أداء أعضاء هيئة التدريس في مجال خدمة الجامعة إلي

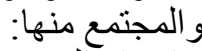
- إجر اء البحوث التطبيقية لصالح المؤسسات و المنظمات الجماهيرية.

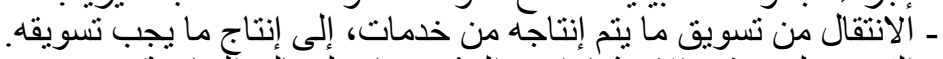

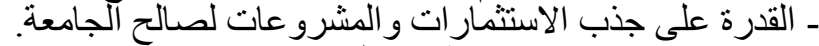

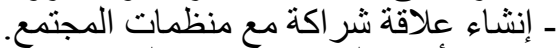

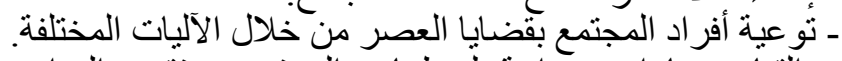

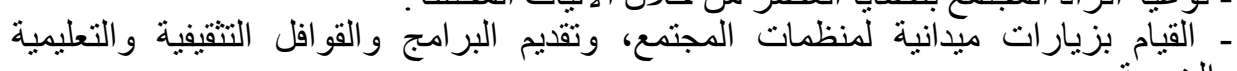

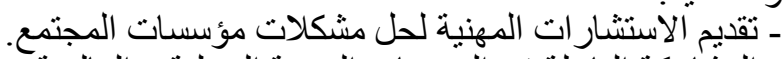

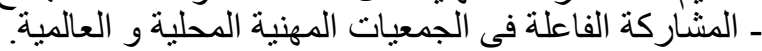

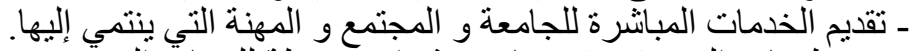

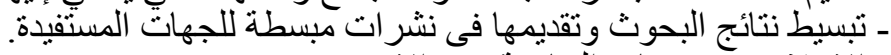

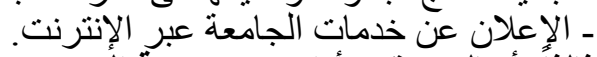

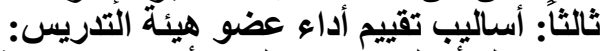
هناك أساليب متعددة لتقييم أداء عضو هيئة التدريس يمكن إجمالها فيما يلي: 


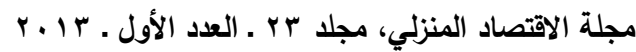

(أ) تقييم الطلاب لعضو هيئة التدريس Students Assessment:

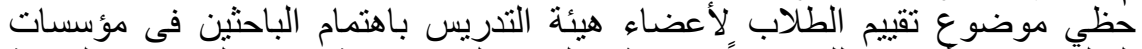

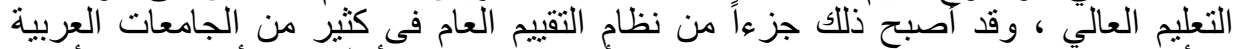

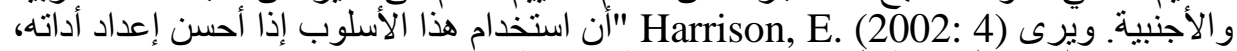

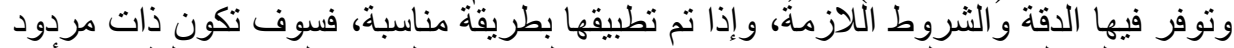

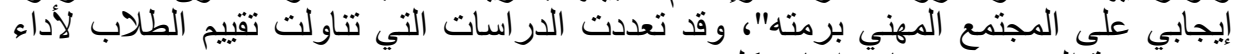
Ballantyne, R. ،Pozo, M. et al. عضو هيئة التدريس ومنها در استات كل من: (2000) Marsh, H. (2001) ،Shevlin, M. et al. (2000) ،et al. (2000)

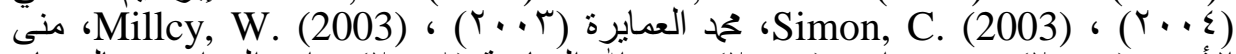

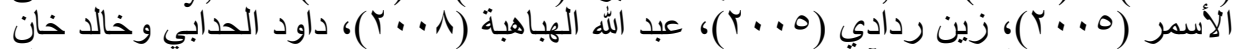

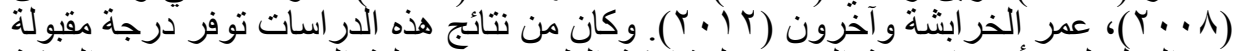

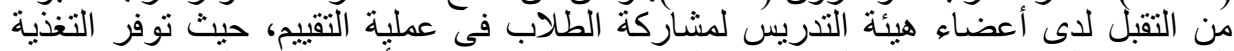

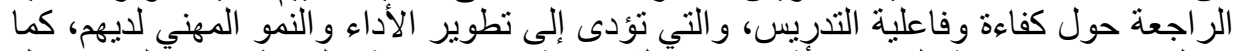

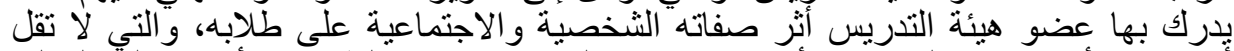

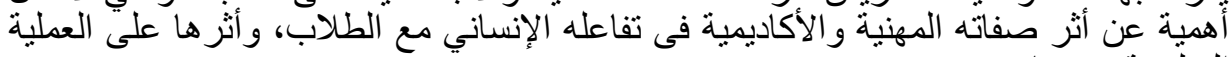

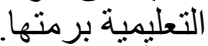

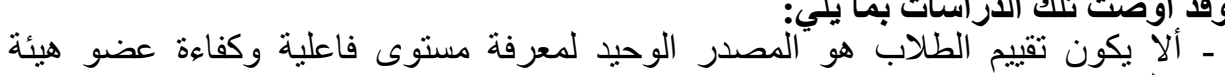

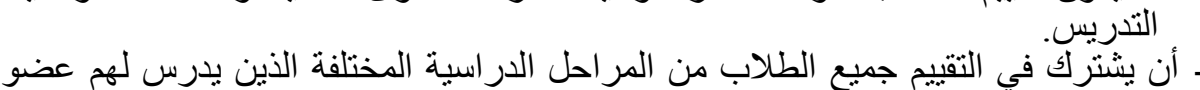

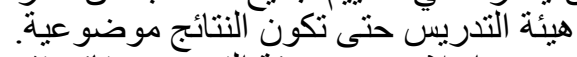

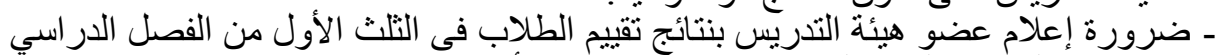

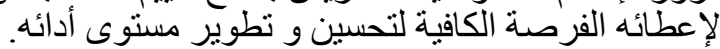

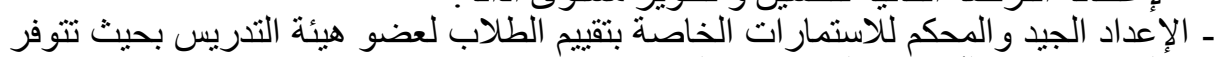
ألموضو عية و البُعد عن المجاملات الثيدات الثخصية.

و على الجانب الآخر فهناك دراسات أخرى تعارض أسلوب تقييم الطلاب لعضو هيئة

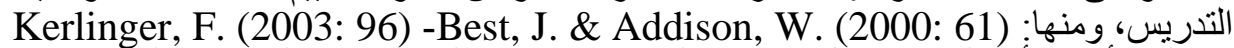

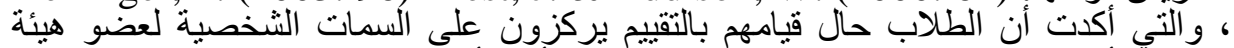

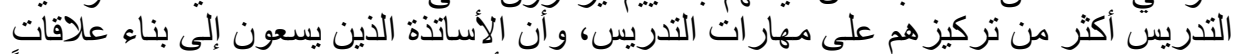

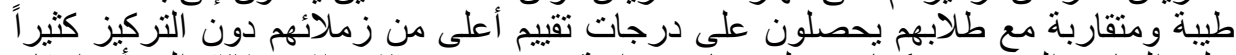

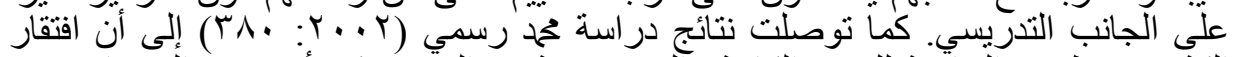

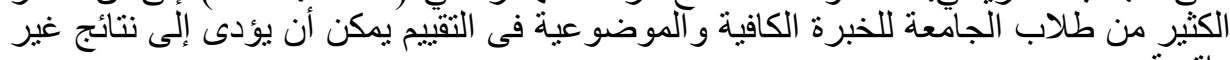

(ب) تقييم الزملاء لعضو هيئة التدريس Peer Assessment

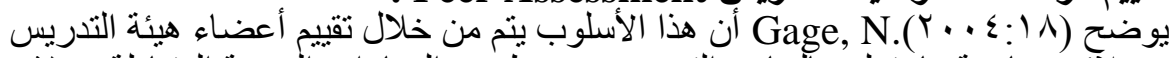

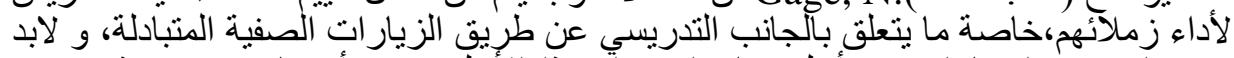

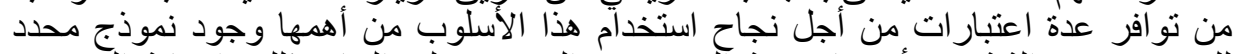

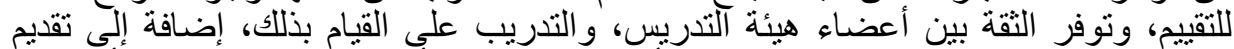

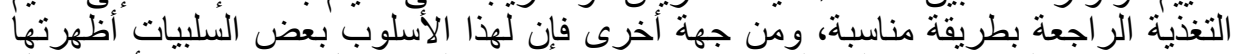

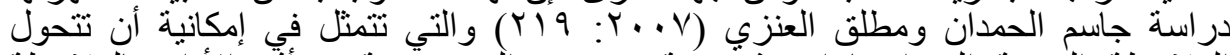

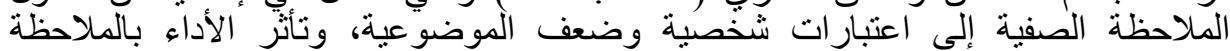
الخارجية، ناهيك عن تدني الروح المعنوية. 


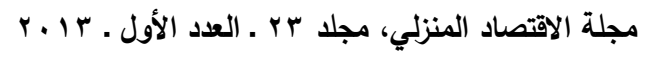

(ج) تقييم رؤساء العمل Supervisory Assessment

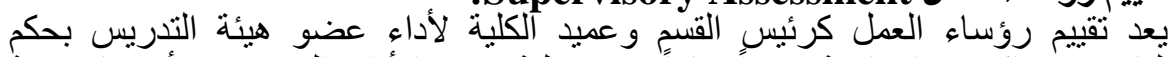

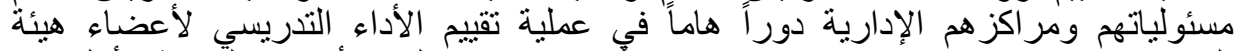

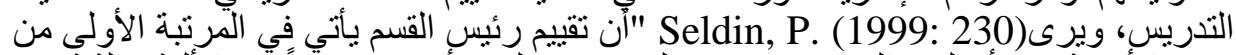

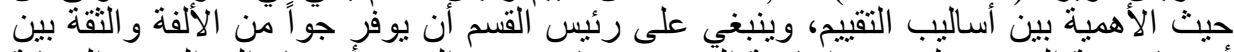

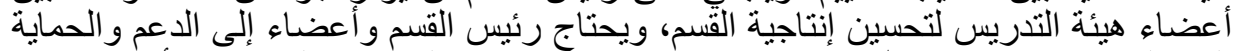

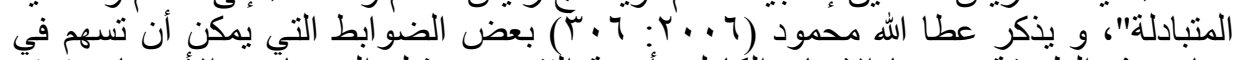

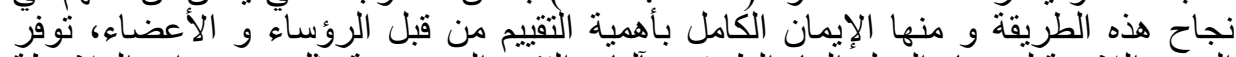

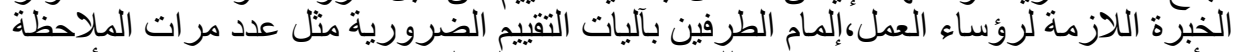

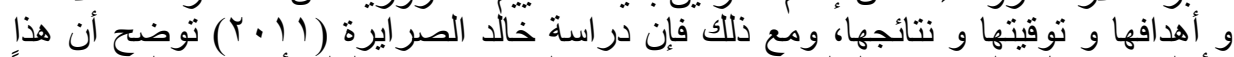

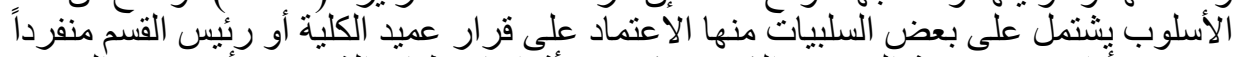

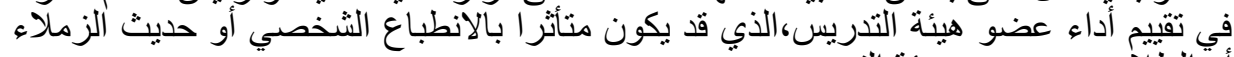

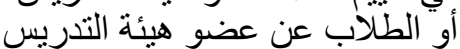

(د) التقييم الذاتي لأداء عضو هيئة التدريس Self-Assessment

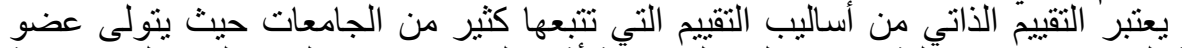

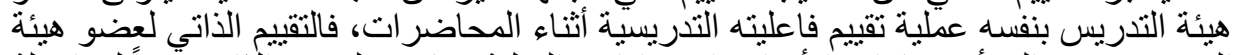

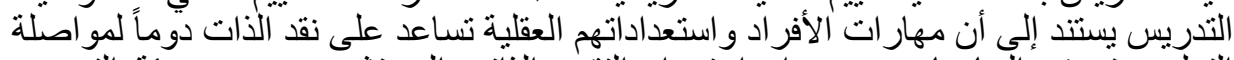

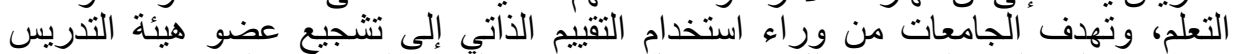

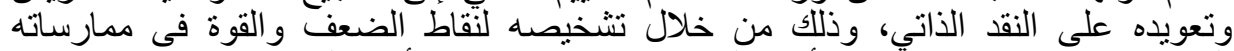

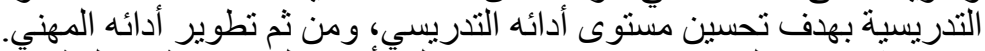

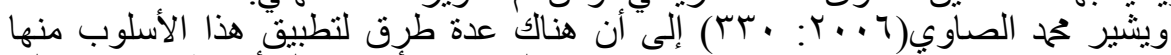

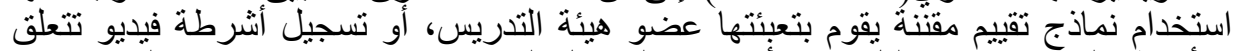

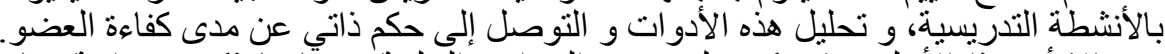

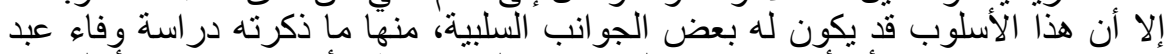

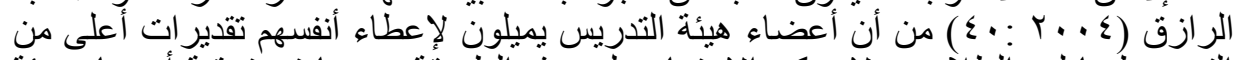

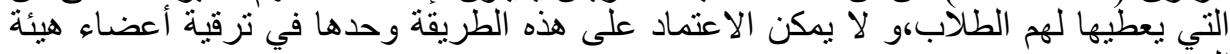

(هـ) التقييم القائم على المعايير Standard-Based Assessment

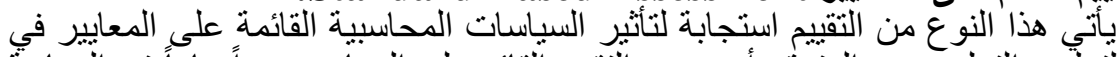

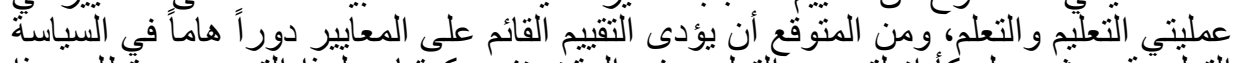

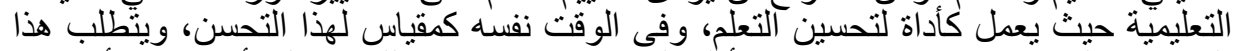

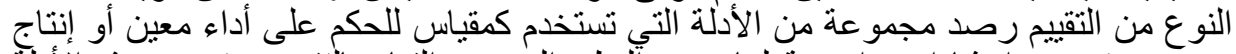

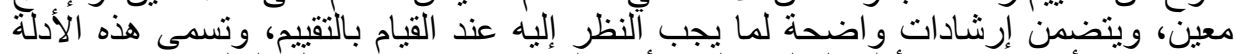

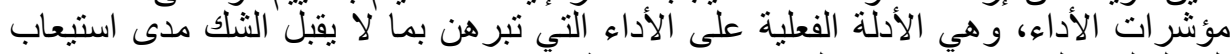

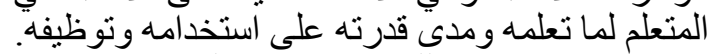

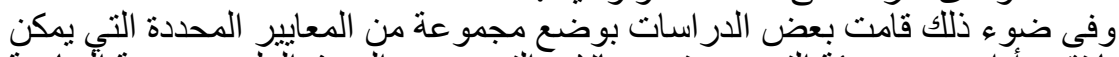

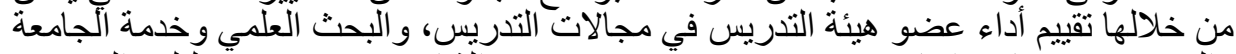

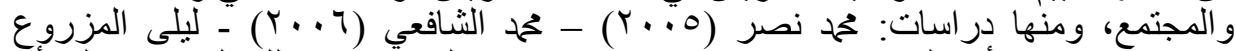
(Y..V)

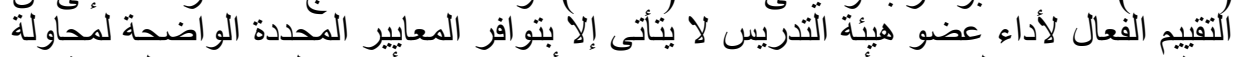

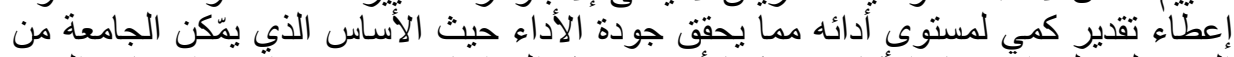

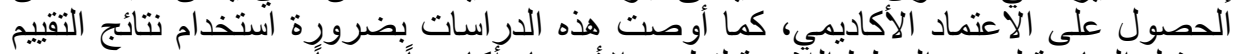

من قبل الجامعة لوضع الخطط اللَّزمة لتطوير الأعضاء أكاديمياً ومهنيا. 


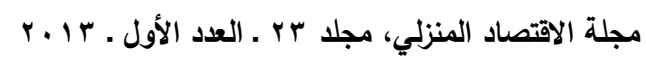

رابعاً: خبرات بعض الجامعات العربية والأجنبية فى تقييم أداء عضو هيئة التّريس":

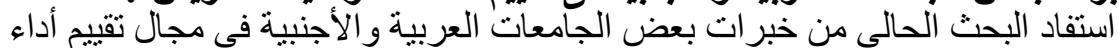

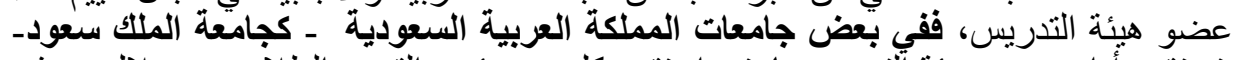

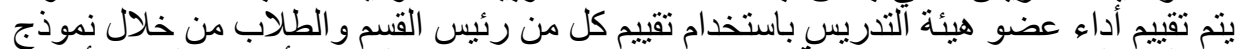
معد لهذا الغرض، بينما في جامعة الملك عبد العزيز يتم استخدام الملف الأكاديمي لرئ الرصد أنثطنة

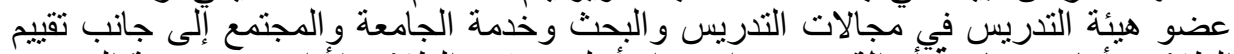

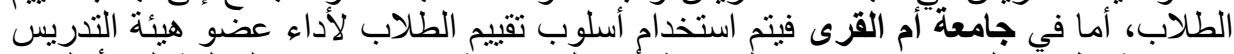

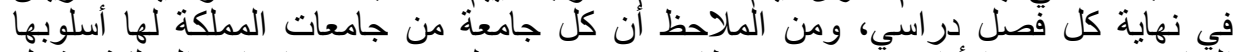
الخاص في تقييم الأداء، ؤلا يوجد نظام تقييم موحد على مستوى جامعات المات المملكة يشمل

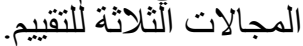

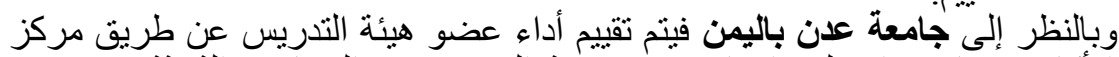

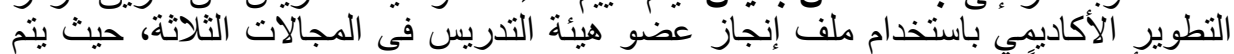

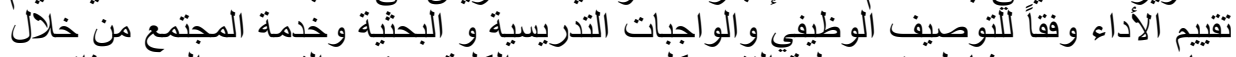

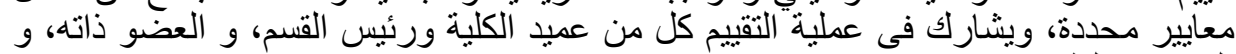

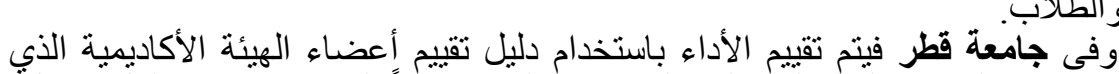

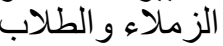

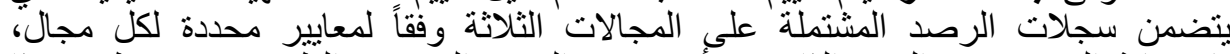

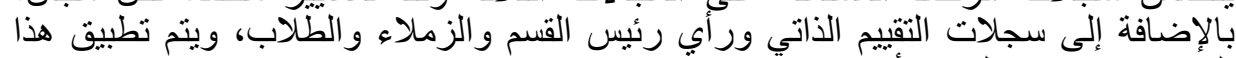

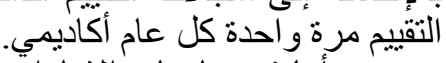

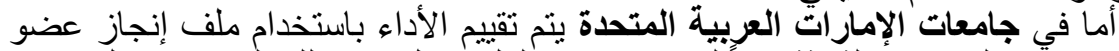

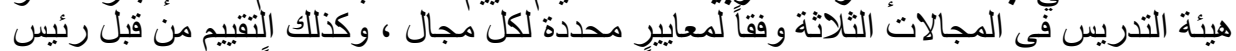

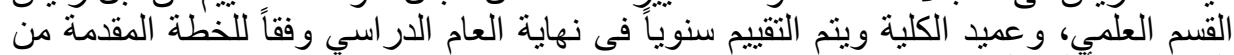

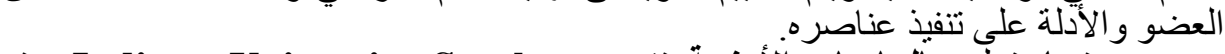

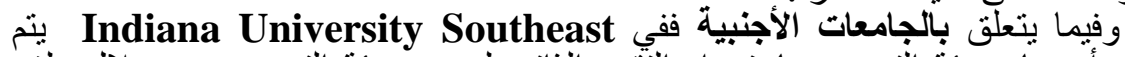

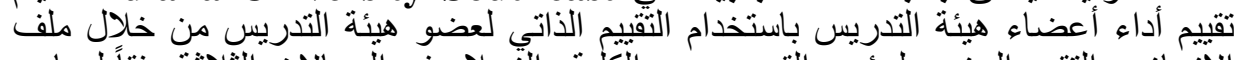

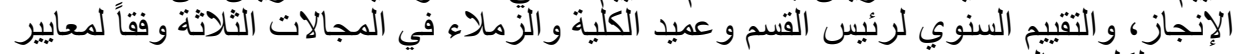
Central Florida University

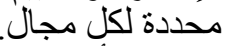

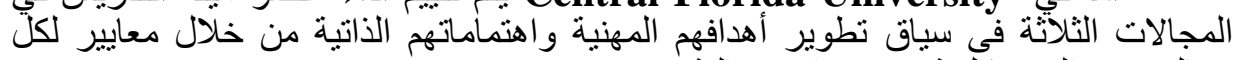

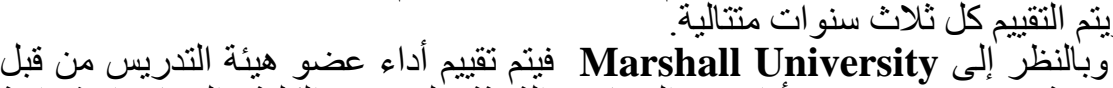

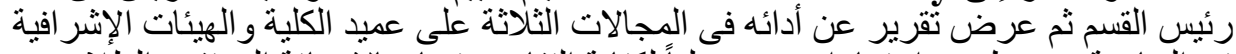

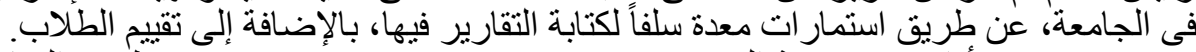

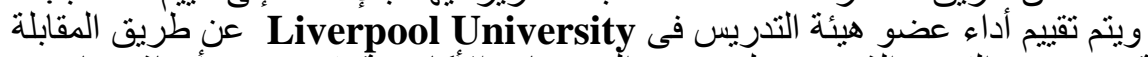

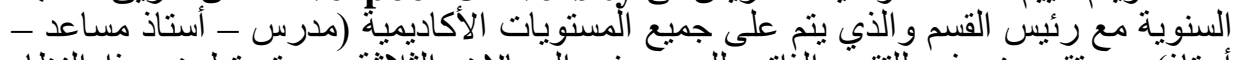

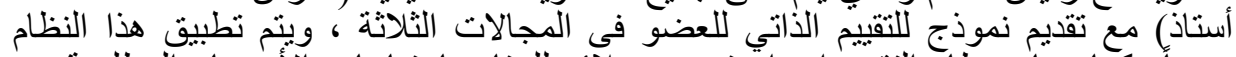

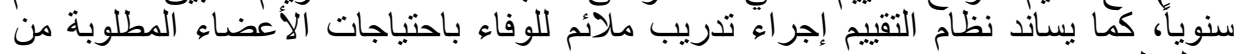

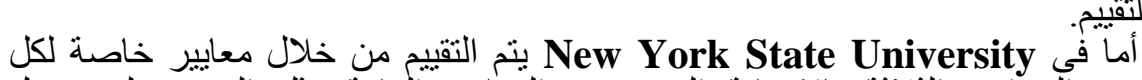

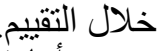
جانب من الجوانب الثناثة بالإضافة إلى بعض الثض المعايير الكعامة مثل القدرة على تحمل المسئوليات المهنية و الوعي بالأهداف الجامعية.

• انظر تلك الجامعات في قائمة المراجع. 


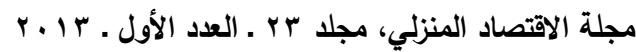

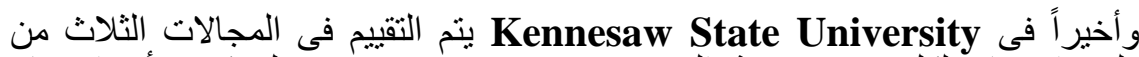
خلال ملف الإنجاز لكل عضو هيئة التدريس، حيث يوضح من خلاله كيف أن أن الإنجاز

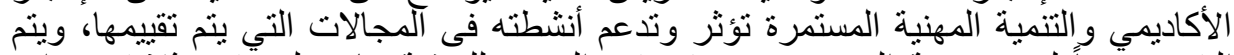

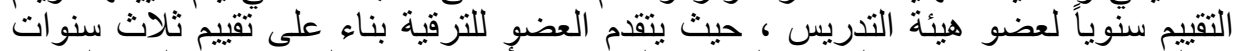

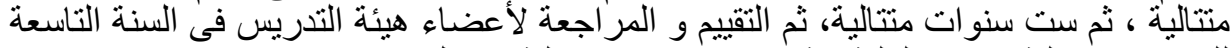

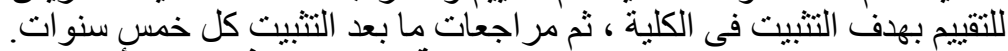

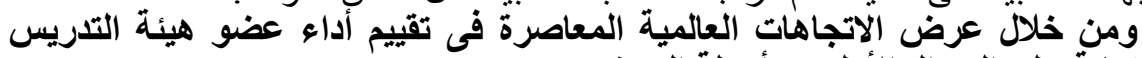

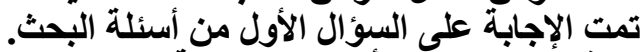

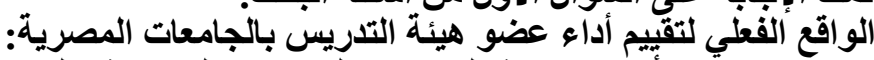

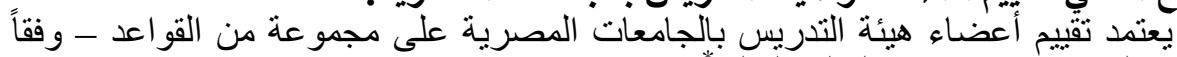

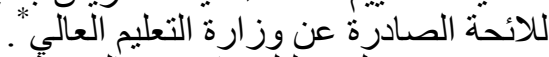

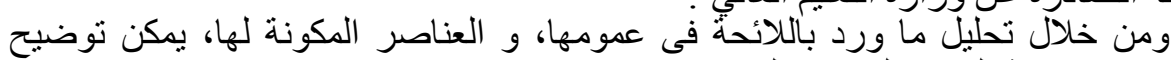

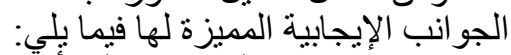

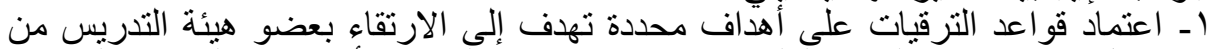

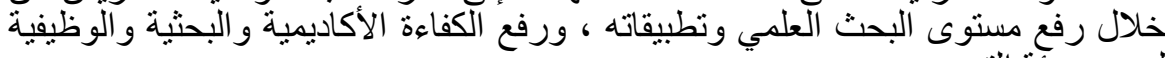
لب لعضو هيئة التندريس.

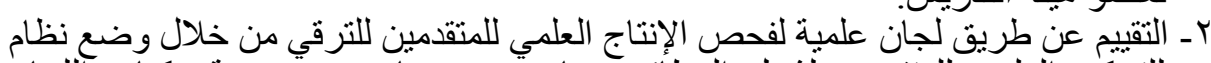

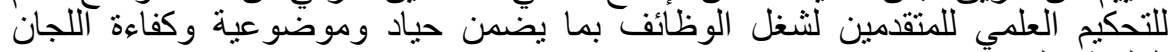

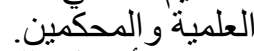
r- خضوع أعمال اللجان و المحكمين لإطار عام بؤكد على توحبد مقاييس التقبيم وتطبيق

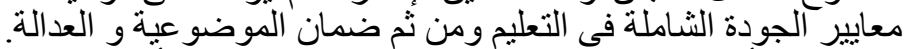

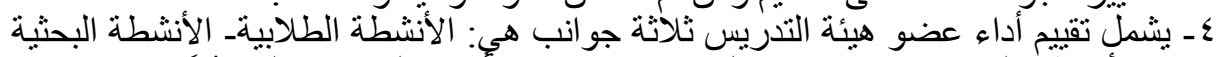

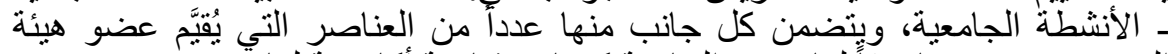

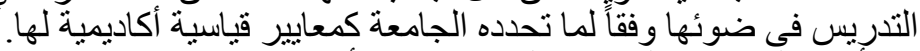

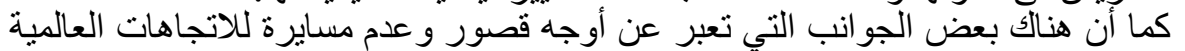

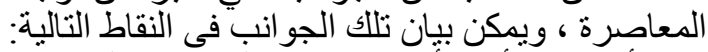

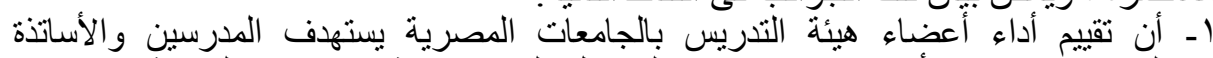

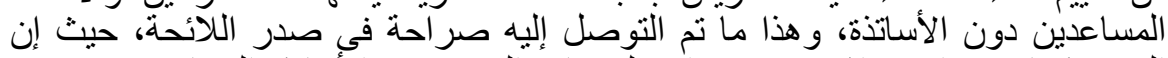

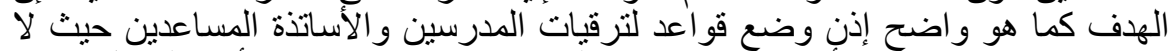

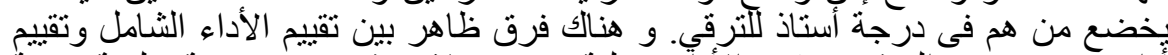

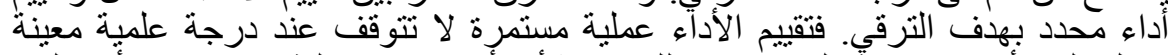

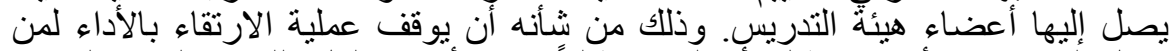

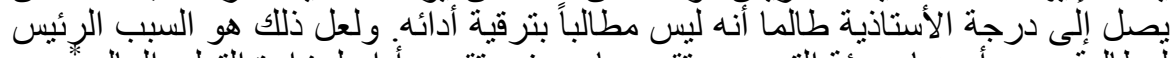

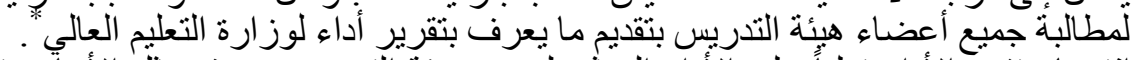

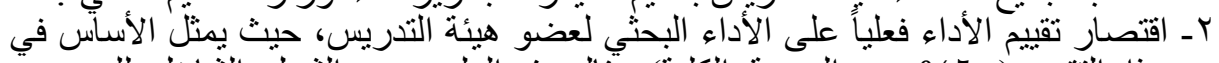

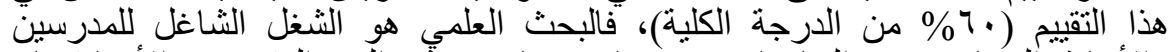

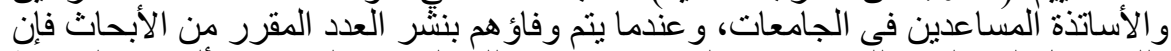

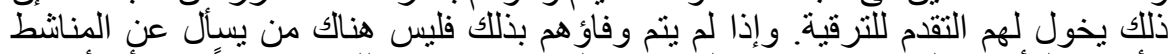

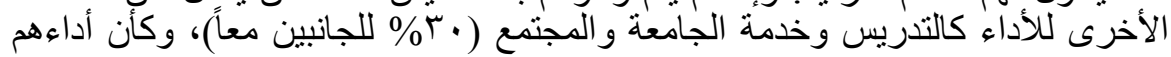

* تم الاعتماد فى عرض المعلومات الواردة بهذا الجزء على النسخة النهائية للائحة قواعد ونظام عمل اللجان العلمية لفحص الإنتاج العلمي للمتقدمين لشغل

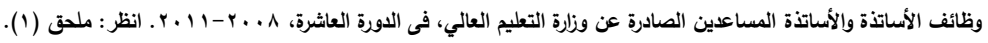
* انظر : ملحق (r) تقرير ذاتي عن أنشطة وإنجازات عضو هيئة التدريس. 


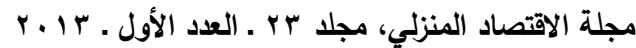

الفعلي يتمثل فقط فى البحث العلمي. فهناك من لم يتقدم للترقية لسبب أو لآخر فيظل في

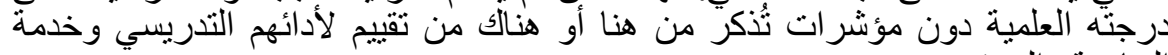

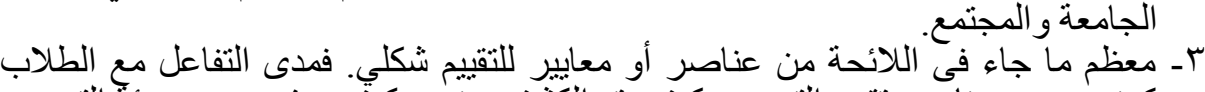

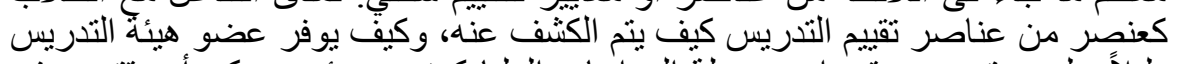

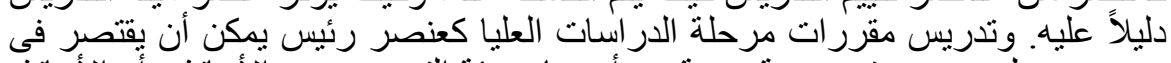

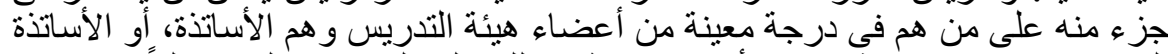

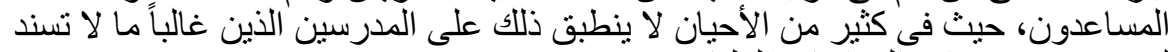

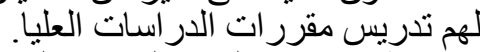

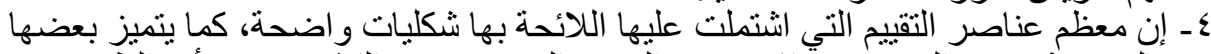

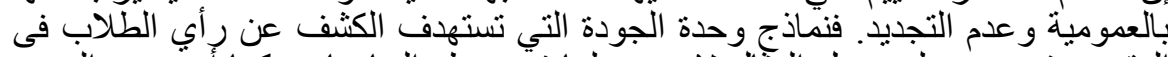

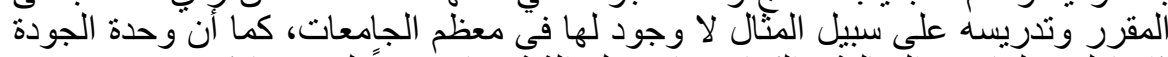

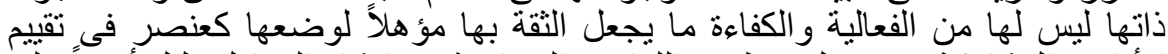

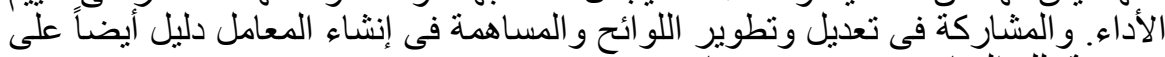
عمومية تلاك العناصر و وعدم تعدئ تحديدها.

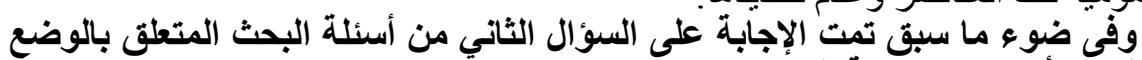

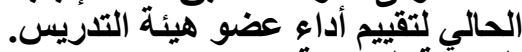

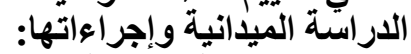

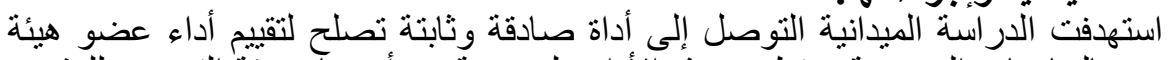

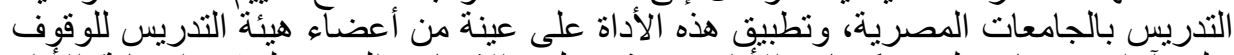

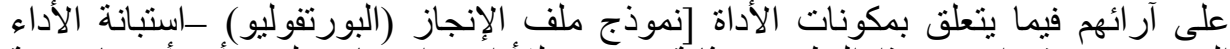

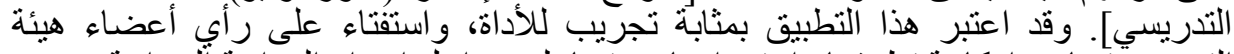

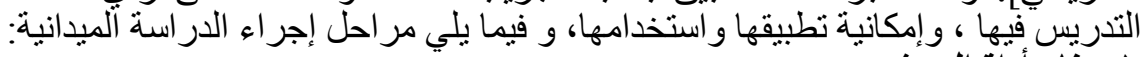

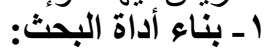

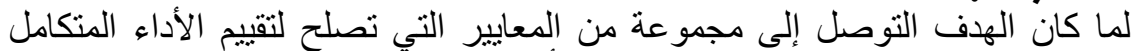

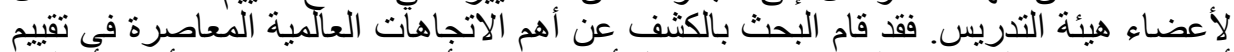

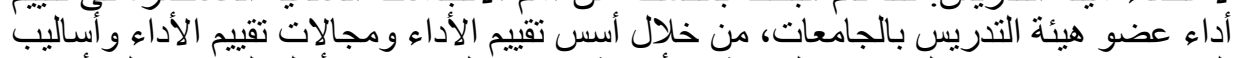

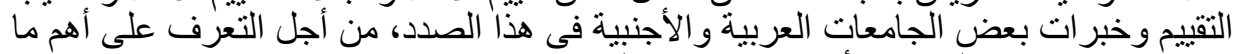

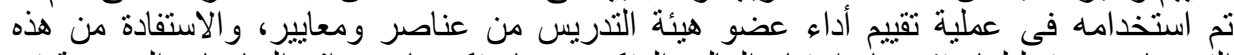

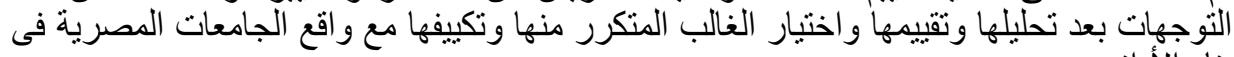

$$
\text { وقد توصل البحث إلى وضع صورة أولية للأداة* تكونت من الآتي: }
$$

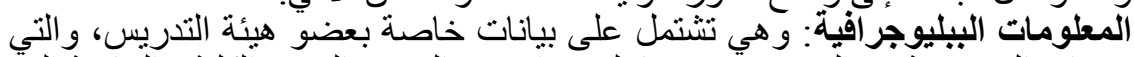

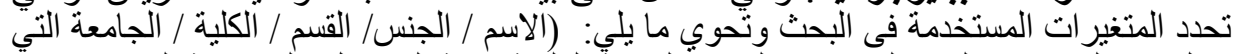

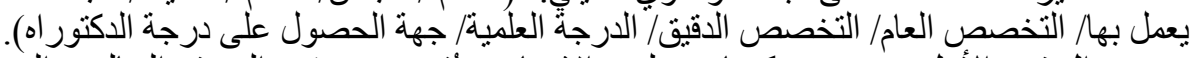

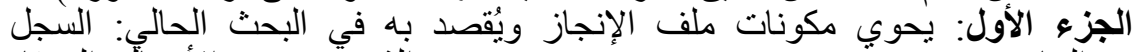

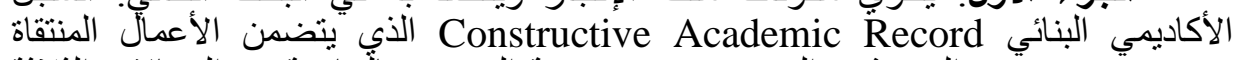
Selected works

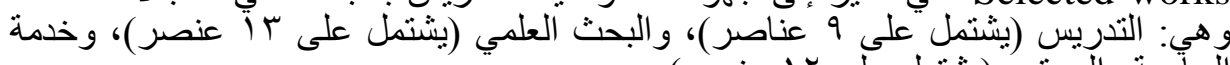
الجأمعة و المجتمع (يشتمل على على أل عنصر).

" ملحق (ץ) الصورة الأولية لاستمارة استقصاء حول نموذج تقييم أداء عضو هيئة التلريس بالجامعات المصرية. 
أما الجزء الثاني: فهو عبارة عن استبانة لتقييم الأداء التدريسي لعضو هيئة التدريس

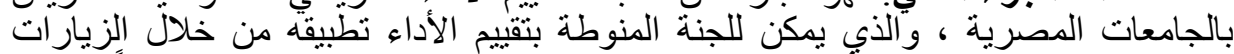

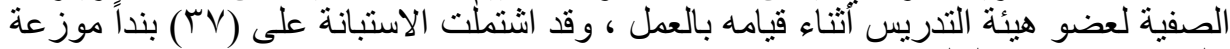

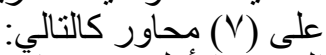

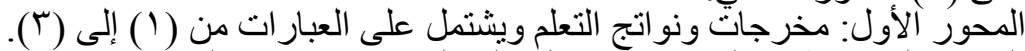

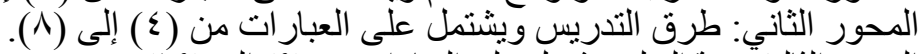

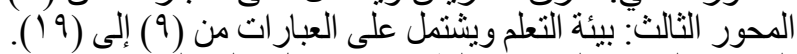

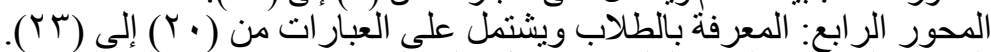

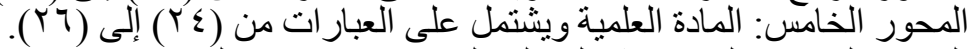

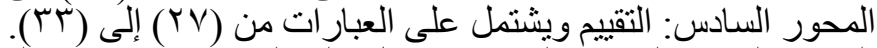

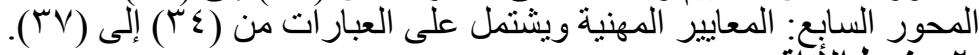

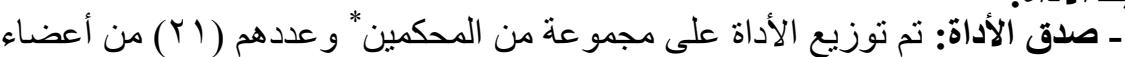

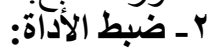

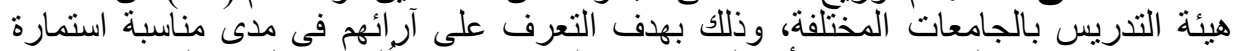

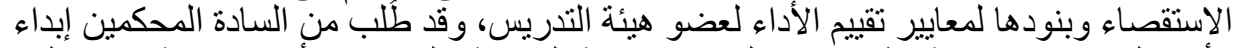

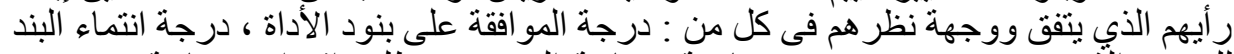

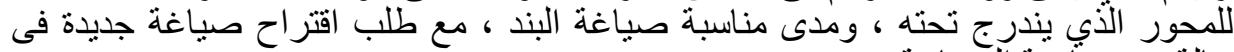
حالة عدم منأسبة الصياغة.

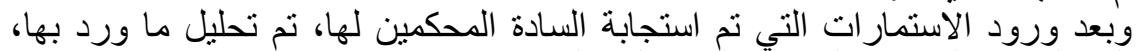

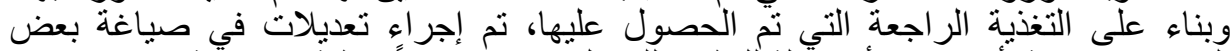

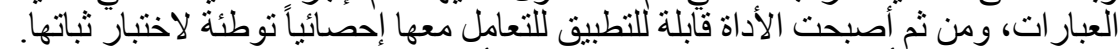

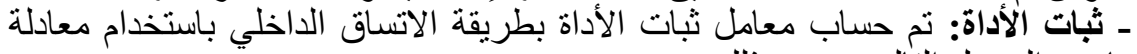

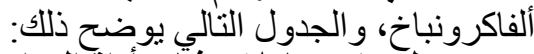
جدول (1) معاملات ثبات أداةً الدر اسة بمحوريها بطريقة الاتساق الداخلي

\begin{tabular}{|c|c|c|}
\hline كرونباخ الفا & المحــور & r \\
\hline$\cdot \wedge \wedge 1$ & معايير أداء عضو هيئة التذريس باستخدام ملف الإنجاز محور التذريس. & 1 \\
\hline $.9 \leqslant V$ & معايير اداء عضو هيئة التدريس باستخدام ملف الإنجاز محور البحث العلمي. & T \\
\hline .901 & معايير أداء عضو هيئة التدريس باستخدام ملف الإنجاز محور خدمة الجامعة والّجتمع & r \\
\hline $.9 \vee \leqslant$ & معايير أداء عضو هيئة التذريس باستخدام ملف الإنجاز ملف الإنجاز ككل. & $\varepsilon$ \\
\hline$\because V \leq 0$ & معايير أداء عضو هيئة التدريس باستخدام (الاستبانة) محور مخرجات و نواتج التعلم. & 0 \\
\hline$\cdot \wedge \curlywedge \wedge$ & معايير أداء عضو هيئة التذريس باستخدام (الاستبانة) محور طرق التذريس. & 7 \\
\hline $.9 \mathrm{M}$ & معايير أداء عضو هيئة التدريس باستخدام (الاستبانة ) محور بيئة التعلم. & $\mathrm{V}$ \\
\hline .909 & معايير أداء عضو هيئة التذريس باستخدام (الاستبانة ) التعامل مع الطلاب. & $\Lambda$ \\
\hline$\cdot \wedge \wedge \varepsilon$ & معايير أداء عضو هيئة التدريس باستخدام (الاستبانة ) محور المادة العلمية. & 9 \\
\hline $.9 Y 0$ & معايير أداء عضو هيئة التدريس باستخدام (الاستبانة ) محور التقييم. & $1 \cdot$ \\
\hline. $\mathrm{V00}$ & معايير أداء عضو هيئة التدريس باستخدام (الاستبانة ) محور المعايير المهنية. & 11 \\
\hline $.9 \vee \wedge$ & معايير أداء عضو هبئة التدريس باستخدام (الاسنبانة) ككل. & TY \\
\hline
\end{tabular}

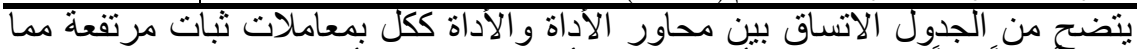

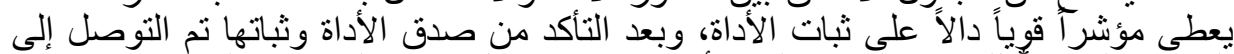

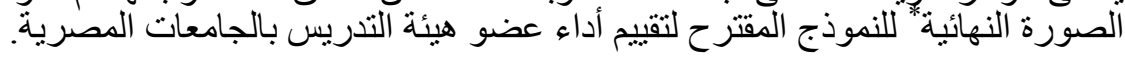




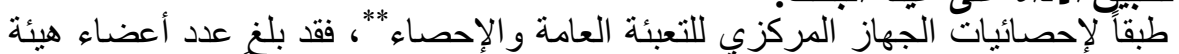

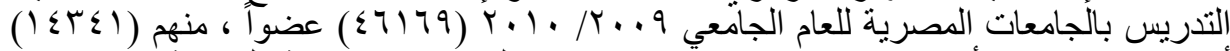

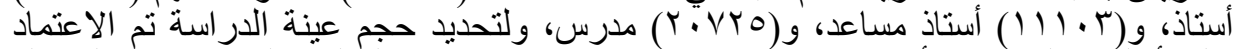

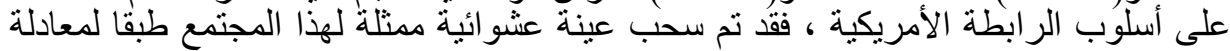
(Marguerite, G. \& Others , 2006: 146) "Krejcie and Morgan (1970)"

$$
S=\frac{x^{2} N P(1-P)}{d^{2}(N-1)+X^{2} P(1-P)}
$$

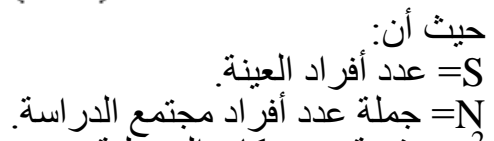

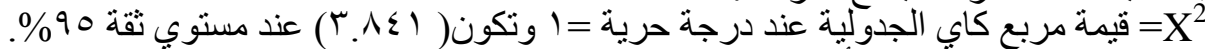

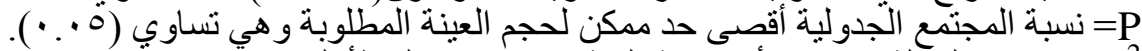

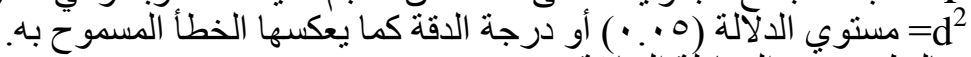

$$
\mathrm{N}=\frac{(3.841)(46196)(0.5)(1-0.5)}{(0.05)^{\circ}(46196-1)+3.841(0.5)(1-0.5)}
$$

$\mathrm{N}=380.94 \approx 381$

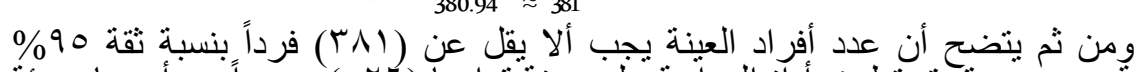

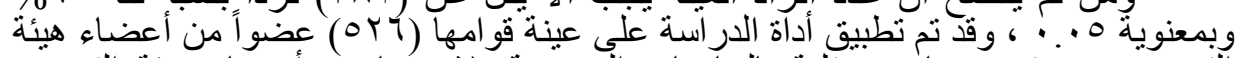

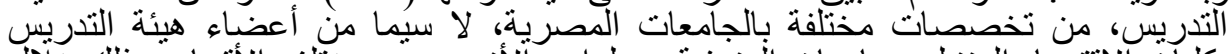

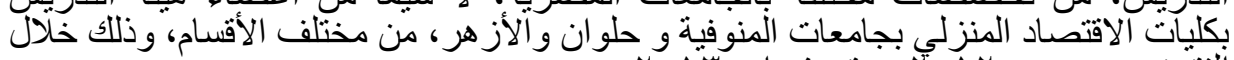

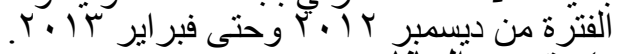

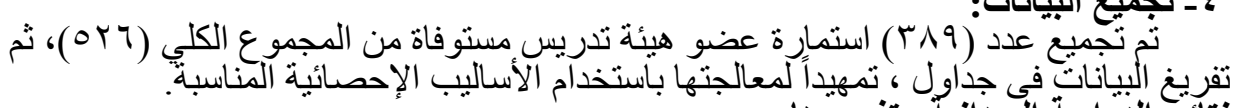
كـ - تجميع ألبيانات:

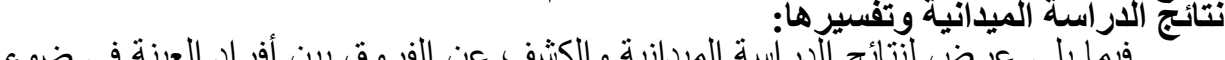

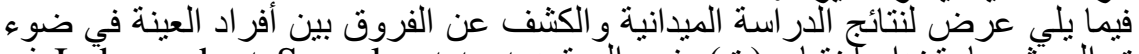

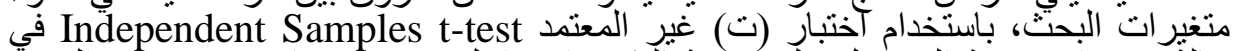

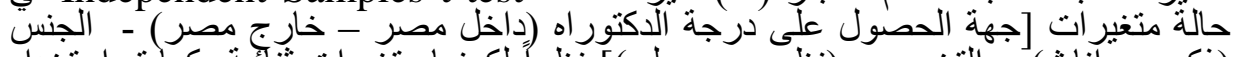

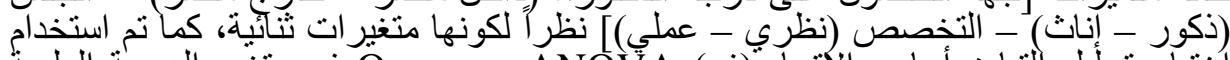

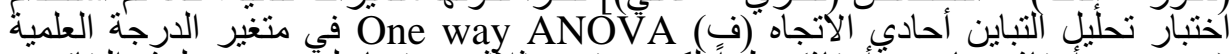

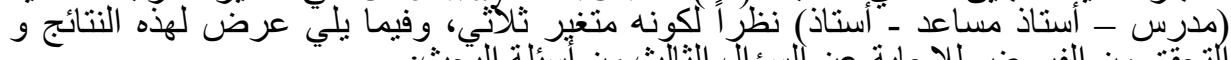

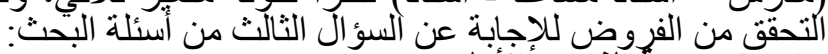

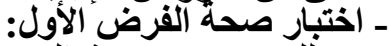

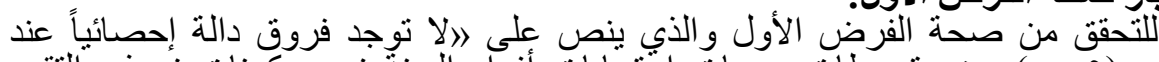

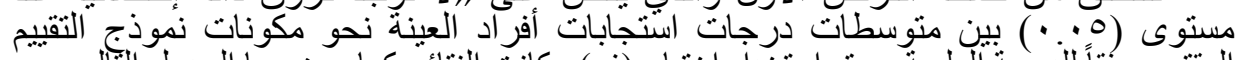

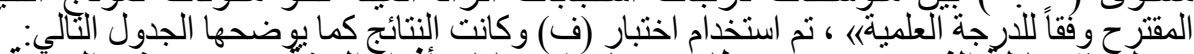

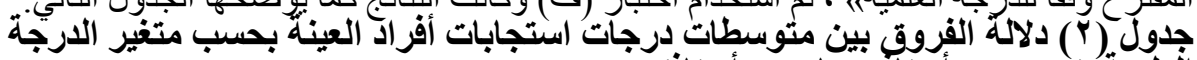
ألُعلمية (مدرس - أستاذ مستاعد - أستاذ)

"* الجهاز المركزي للتعبئة العامة و الإحصاء (مارس Y ب. ب): مصر فى أرقام. 
مجلة الاقتصاد المنزلي، مجلد بr ـ العدد الأول ـ r ا ـ r

\begin{tabular}{|c|c|c|c|c|c|c|}
\hline الإحصائية الدلاية & قيمة & الانعراف & المتوسط & $\mathrm{N}$ & العلمية الدة & المحاور \\
\hline \multirow{4}{*}{$\begin{array}{l}0.001 \\
0\end{array}$} & \multirow{4}{*}{34.197} & 10.27 & 111.93 & 189 & مدرس & \multirow{4}{*}{ ملف الإنجاز } \\
\hline & & 20.21 & 98.62 & 104 & استاذ مساعد & \\
\hline & & $\begin{array}{lll}11.47 \\
\end{array}$ & $\begin{array}{lll}111.43 \\
\end{array}$ & 96 & استاذ & \\
\hline & & 15.03 & $\begin{array}{ll}108.25 \\
\end{array}$ & 389 & الإجهالي & \\
\hline \multirow{4}{*}{$\begin{array}{l}0.001 \\
\text { دالة }\end{array}$} & \multirow{4}{*}{35.249} & 19.20 & 213.69 & 189 & مدرس & \multirow{4}{*}{ مجموع الاستبانة } \\
\hline & & 42.44 & 185.88 & 104 & استاذ مساعد & \\
\hline & & 24.39 & 212.10 & 96 & استاذ & \\
\hline & & 30.81 & 205.86 & 389 & الاجهالي & \\
\hline \multirow{4}{*}{$\begin{array}{l}0.001 \\
\text { دالة }\end{array}$} & \multirow{4}{*}{13.479} & 1.70 & 16.85 & 189 & مدرس & \multirow{4}{*}{ البيانات العامة } \\
\hline & & 2.38 & 15.73 & 104 & استاذ مساعد & \\
\hline & & 1.70 & 16.89 & 96 & استاذ & \\
\hline & & 1.96 & $\begin{array}{ll}16.56 \\
\end{array}$ & 389 & الاجهالي & \\
\hline \multirow{4}{*}{$\begin{array}{l}0.001 \\
\text { دالة }\end{array}$} & \multirow{4}{*}{32.238} & 2.69 & 24.88 & 189 & مدرس & \multirow{4}{*}{ مجهوع التدريس } \\
\hline & & 4.27 & 21.88 & $\overline{104}$ & استاذ مساعد & \\
\hline & & 2.95 & 24.81 & 96 & استاذ & \\
\hline & & 3.50 & 24.06 & 389 & الاجمالي & \\
\hline \multirow{4}{*}{$\begin{array}{l}0.001 \\
\text { دالة }\end{array}$} & \multirow{4}{*}{35.755} & 3.77 & 36.23 & 189 & مدرس & \multirow{4}{*}{ البحث العلمي } \\
\hline & & 7.79 & 31.05 & 104 & استاذ مساعد & \\
\hline & & 4.45 & 36.05 & 96 & استاذ & \\
\hline & & 5.75 & 34.80 & 389 & الاجهالي & \\
\hline \multirow{4}{*}{$\begin{array}{l}0.001 \\
0\end{array}$} & \multirow{4}{*}{28.838} & 3.11 & 33.96 & 189 & مدرس & \multirow{4}{*}{ خدمة الجامعة والمجتمع } \\
\hline & & 6.85 & 29.96 & $\overline{104}$ & استاذ مساعد & \\
\hline & & 3.49 & 33.68 & 96 & استاذ & \\
\hline & & 4.81 & 32.82 & 389 & الاجهالي & \\
\hline \multirow{4}{*}{$\begin{array}{l}0.001 \\
\text { دالة }\end{array}$} & & $\overline{1.04}$ & 8.31 & 189 & مدرس & \\
\hline & 29.189 & 1.96 & 7.10 & 104 & استاذ مساعد & \\
\hline & 29.189 & 1.01 & 8.18 & 96 & استاذ & مخرجات ونواتج التعلم \\
\hline & & 1.43 & 7.95 & 389 & الاجهالي & \\
\hline & & 1.87 & 13.76 & 189 & مدرس & \\
\hline 0.001 & & 3.13 & 11.83 & 104 & استاذ مساعد & \\
\hline دالة & 25.403 & 2.19 & 13.70 & 96 & استاذ & طرق التدريس \\
\hline & & 2.49 & 13.23 & 389 & الاجهالي & \\
\hline & & 3.22 & 30.51 & 189 & مدرس & \\
\hline 0.001 & 33.200 & 6.56 & 26.14 & 104 & استاذ مساءد & مجموع \\
\hline دالة الة & 33.200 & 3.90 & 29.92 & 96 & استاذ & بيئة التعلم \\
\hline & & 4.86 & 29.20 & 389 & الاجهالي & \\
\hline & & $\overline{1.71}$ & 10.69 & 189 & مدرس & \\
\hline 0.001 & & 2.70 & 9.32 & 104 & استاذ مساعد & \\
\hline دالة & 17.074 & 1.93 & 10.73 & 96 & استاذ & التعامل مع الطلاب \\
\hline & & 2.15 & 10.33 & 389 & الاجهالي & \\
\hline & & 0.93 & 8.52 & 189 & مدرس & \\
\hline 0.001 & 26268 & 2.24 & 7.25 & 104 & استاذ مساعد & - \\
\hline دالة الة & & 1.36 & 8.40 & 96 & استاذ & مجهوع الهادة العلهية \\
\hline & & 1.58 & 8.15 & 389 & الاجهالي & \\
\hline & & 2.48 & 19.19 & 189 & مدرس & \\
\hline 0.001 & & 4.57 & 16.63 & 104 & استاذ مساعد & \\
\hline دالة & 23.515 & 2.90 & 19.19 & 96 & استاذ & مجهوع التقييم \\
\hline & & 3.44 & 18.50 & 389 & الاجهالي & \\
\hline & & 1.28 & 10.78 & 189 & مدرس & \\
\hline 0.001 & & 2.81 & 9.00 & 104 & استاذ مساعد & \\
\hline مالة & 29.467 & 1.95 & 10.57 & 96 & استاذ & مجموع الهعايير الههنية \\
\hline & & 2.10 & 10.25 & 389 & جمالي & \\
\hline
\end{tabular}

يتضح من الجدول السابق وجود فروق دالئة إحصائياً عند مسنوى معنوية (0 . . • ) بين

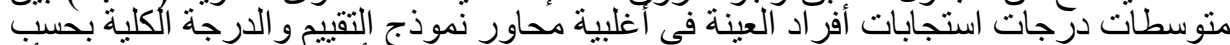

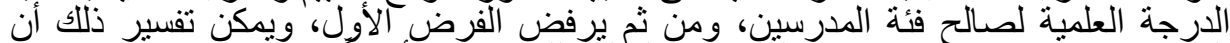
المدرسين هم في بداية عهدهم بالممارسة الفعلية للتدريس، وأيضا في بداية عهذهم بتكوين 


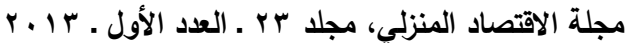

ملفات إنجاز اتهم، فهم بريدون أن يثبتوا أنفسهم ويظهرو ا كفاءاتهم في هذا الصدد ، ومن ثم فهم

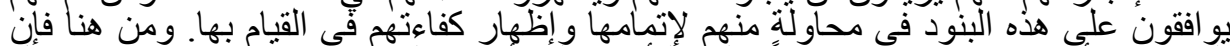

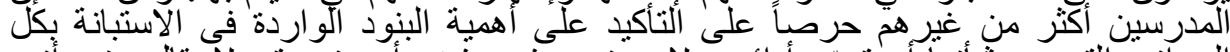

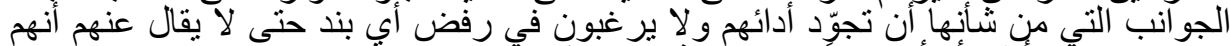

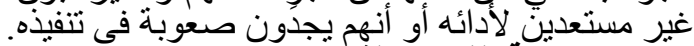

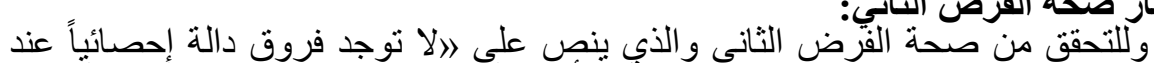

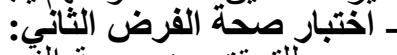

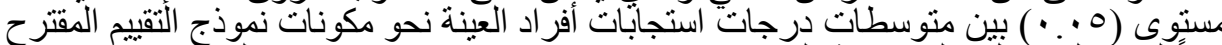

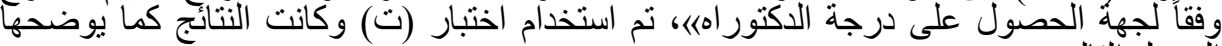

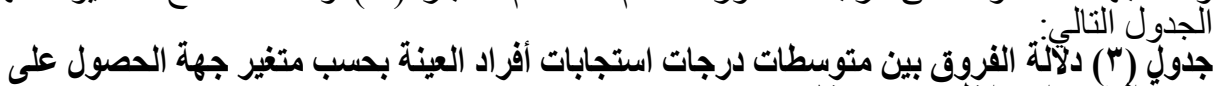

\begin{tabular}{|c|c|c|c|c|c|c|}
\hline الإحصائية & (تيمة & الالنحياري & الهتوسط & $\mathrm{N}$ & على الدكتوراه & المحاور \\
\hline \multirow{3}{*}{$\begin{array}{l}0.001 \\
\text { دالة }\end{array}$} & \multirow{3}{*}{-4.380} & 15.68 & 106.65 & 314 & داخل مصر & \multirow{3}{*}{ ملف الإنجاز } \\
\hline & & 9.34 & 114.92 & 75 & خارج مصر & \\
\hline & & 15.03 & 108.25 & 389 & الاجمالي & \\
\hline \multirow{3}{*}{$\begin{array}{c}0.001 \\
\text { دالة }\end{array}$} & \multirow{3}{*}{-4.136} & 32.19 & 202.77 & 314 & داخل مصر & \multirow{3}{*}{ مجموع الاستبانة } \\
\hline & & 19.54 & 218.81 & 75 & خارج مصر & \\
\hline & & 30.81 & 205.86 & 389 & الاجمالي & \\
\hline \multirow{3}{*}{$\begin{array}{c}0.001 \\
\text { دالة }\end{array}$} & \multirow{3}{*}{-3.378} & 2.04 & 16.40 & 314 & داخل مصر & \multirow{3}{*}{ البيانات العامة } \\
\hline & & 1.44 & 17.24 & 75 & خارج مصر & \\
\hline & & 1.96 & 16.56 & 389 & الاجمالي & \\
\hline \multirow{3}{*}{$\begin{array}{l}0.001 \\
\text { دالة }\end{array}$} & \multirow{3}{*}{-4.693} & 3.64 & 23.67 & 314 & داخل مصر & \multirow{3}{*}{ مجهوع التدريس } \\
\hline & & 2.13 & 25.72 & 75 & خارج مصر & \\
\hline & & 3.50 & 24.06 & 389 & الاجمالي & \\
\hline \multirow{3}{*}{$\begin{array}{l}0.001 \\
\text { دالة }\end{array}$} & \multirow{3}{*}{-4.487} & 5.98 & 34.18 & 314 & داخل مصر & \multirow{3}{*}{ البحث العلمي } \\
\hline & & 3.62 & 37.41 & 75 & خارج مصر & \\
\hline & & 5.75 & 34.80 & 389 & الاجمالي & \\
\hline \multirow{3}{*}{$\begin{array}{l}0.001 \\
\text { دالة }\end{array}$} & \multirow{3}{*}{-3.504} & 5.06 & 32.41 & 314 & داخل مصر & \multirow{3}{*}{ خدمة الجامعة والهجتمع } \\
\hline & & 3.07 & 34.55 & 75 & خارج مصر & \\
\hline & & 4.81 & 32.82 & 389 & الاجهالي & \\
\hline \multirow{3}{*}{$\begin{array}{l}0.001 \\
\text { دالة }\end{array}$} & \multirow{3}{*}{-4.660} & 1.50 & 7.79 & 314 & داخل مصر & \multirow{3}{*}{ مجموع مخرجات } \\
\hline & & 0.87 & 8.63 & 75 & خارج مصر & \\
\hline & & 1.43 & 7.95 & 389 & الاجمالي & \\
\hline \multirow{3}{*}{$\begin{array}{l}0.001 \\
\text { دالة }\end{array}$} & \multirow{3}{*}{-4.269} & 2.56 & 12.97 & 314 & داخل مصر & \multirow{3}{*}{ طرق التدريس } \\
\hline & & 1.79 & 14.31 & 75 & خارج مصر & \\
\hline & & 2.49 & 13.23 & 389 & الاجمالي & \\
\hline \multirow{3}{*}{$\begin{array}{l}0.001 \\
\text { دالة }\end{array}$} & \multirow{3}{*}{-3.721} & 5.04 & 28.75 & 314 & داخل مصر & \\
\hline & & 3.46 & 31.04 & 75 & خارج مصر & سئة التعلم \\
\hline & & 4.86 & 29.20 & 389 & الاجمالي & \\
\hline & & 2.22 & 10.23 & 314 & داخل مصر & \\
\hline مالة & -1.985 & 1.78 & 10.77 & 75 & خارج مصر & التعاما مع الطلاد \\
\hline & & 2.15 & 10.33 & 389 & الاجمالي & \\
\hline & & 1.67 & 8.00 & 314 & داخل مصر & \\
\hline الم 0.001 & -3.853 & 0.92 & 8.77 & 75 & خارج مصر & الهادة العلمية \\
\hline & & 1.58 & 8.15 & 389 & الاجمالي & \\
\hline & & 3.65 & 18.26 & 314 & داخل مصر & \\
\hline & -2.801 & 2.14 & 19.49 & 75 & خارج مصر & مجموع التقييم \\
\hline & & 3.44 & 18.50 & 389 & الاجمالي & \\
\hline & & 2.19 & 10.11 & 314 & ماخل مصر & \\
\hline مالة & -2.901 & 1.49 & 10.88 & 75 & خارج مصر & مجموع المعايير المهنية \\
\hline & & 2.10 & 10.25 & 389 & الاجمالي & \\
\hline
\end{tabular}




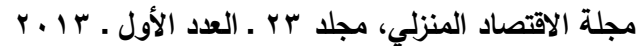

ينضح من الجدول وجود فروق دالة إحصائياً عند مستوى معنوية (0... (ل) بين

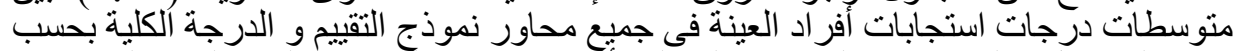

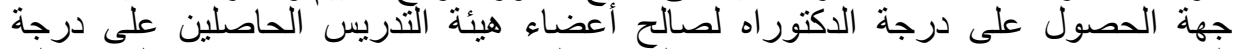

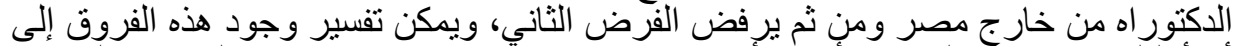

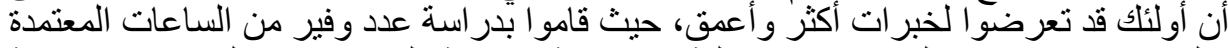

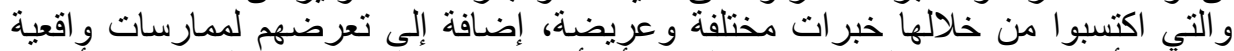

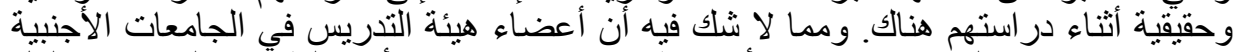

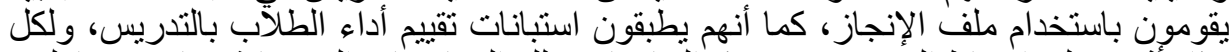

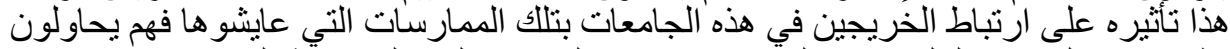

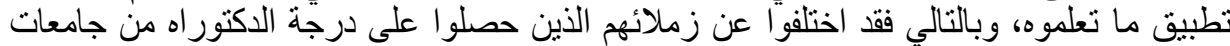

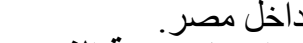
ـ ا ل اختبار صحة الفرض الثالث: للتحقق من صحة الفرض الثالث و الذي ينص على الثى / لا توجد فروق دالة إحصائياً عند

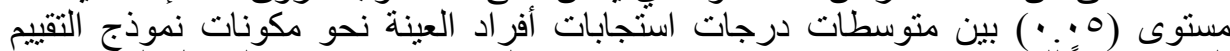

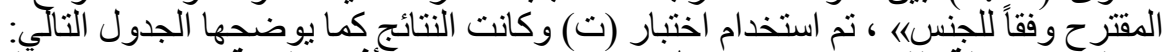

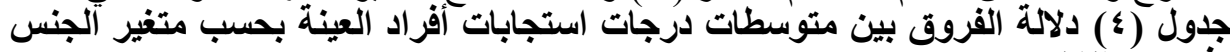

\begin{tabular}{|c|c|c|c|c|c|c|}
\hline الإحصائية & قيمة(ت) & الانحراف الهعياري & الهتوسط & $\mathrm{N}$ & الجنس & المحاور \\
\hline \multirow{3}{*}{ غير دالة. } & \multirow{3}{*}{-1.805} & 15.29429 & 107.1004 & 229 & ذكر & \multirow{3}{*}{ مجموع ملف الإنجاز } \\
\hline & & 14.52129 & 109.8875 & 160 & انثى انى & \\
\hline & & 15.02509 & 108.2468 & 389 & الاجمالى & \\
\hline \multirow{3}{*}{$\begin{array}{c}0.159 \\
\text { غير دالة }\end{array}$} & \multirow{3}{*}{-1.411} & 31.52254 & 204.0218 & 229 & ذكر & \multirow{3}{*}{ مجموع الاستبانة } \\
\hline & & 29.64719 & 208.4938 & 160 & انثى انى & \\
\hline & & 30.80511 & 205.8612 & 389 & الاجمالى & \\
\hline \multirow{3}{*}{$\begin{array}{c}0.364 \\
\text { غير دالة }\end{array}$} & \multirow{3}{*}{-.909} & 1.97927 & 16.4847 & 229 & ذكر & \multirow{3}{*}{ مجموع البيانات العامة } \\
\hline & & 1.94491 & 16.6688 & 160 & انثى انى & \\
\hline & & 1.96479 & 16.5604 & 389 & الاجهالى & \\
\hline \multirow{3}{*}{$\begin{array}{l}0.067 \\
\text { غير دالة }\end{array}$} & \multirow{3}{*}{-1.836} & 3.65985 & 23.7904 & 229 & ذكر & \multirow{3}{*}{ مجموع محور } \\
\hline & & 3.22100 & 24.4500 & 160 & 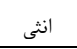 & \\
\hline & & 3.49688 & 24.0617 & 389 & الاجمالى & \\
\hline \multirow{3}{*}{$\begin{array}{l}0.030 \\
\text { دالة }\end{array}$} & \multirow{3}{*}{-2.174} & 5.93890 & 34.2751 & 229 & ذكر & \multirow{3}{*}{ البحث العلمي محور } \\
\hline & & 5.38779 & 35.5563 & 160 & 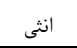 & \\
\hline & & 5.74630 & 34.8021 & 389 & الاجمالى & \\
\hline \multirow{3}{*}{ غير دالة 0.182} & \multirow{3}{*}{-1.338} & 4.90197 & 32.5502 & 229 & ذكر & \multirow{3}{*}{ خدمة الجامعة والهجتمع } \\
\hline & & 4.66404 & 33.2125 & 160 & انثى & \\
\hline & & 4.81052 & 32.8226 & 389 & الاجمالى & \\
\hline \multirow{2}{*}{$\begin{array}{c}0.397 \\
\text { غير دالة }\end{array}$} & \multirow{2}{*}{-.849} & 1.43986 & 7.8996 & 229 & ذكر & \multirow{2}{*}{ مخرجات ونواتج التعلم } \\
\hline & & 1.42727 & 8.0250 & 160 & انثى انثى & \\
\hline
\end{tabular}




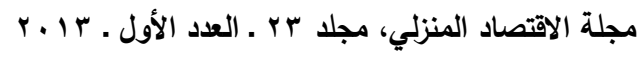

\begin{tabular}{|c|c|c|c|c|c|c|}
\hline \multirow[t]{2}{*}{ الإحصائية } & \multirow[t]{2}{*}{ قيمة(ت) } & الانحراف الهعياري & المتوسط & $\mathrm{N}$ & 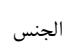 & \multirow[t]{2}{*}{ المحاور } \\
\hline & & 1.43418 & 7.9512 & 389 & الاجمالى & \\
\hline \multirow{3}{*}{$\begin{array}{c}0.552 \\
\text { غير دالة }\end{array}$} & \multirow{3}{*}{-.596} & 2.52331 & 13.1659 & 229 & ذكر & \multirow{3}{*}{ طرق التدريس محور } \\
\hline & & 2.44016 & 13.3188 & 160 & انثى إنى & \\
\hline & & 2.48741 & 13.2288 & 389 & الاجمالى & \\
\hline \multirow{3}{*}{ غير دالة 0.255} & \multirow{3}{*}{-1.140} & 4.91536 & 28.9607 & 229 & ذكر & \multirow{3}{*}{ مجيئة التعلم محور } \\
\hline & & 4.76877 & 29.5313 & 160 & انثى & \\
\hline & & 4.85755 & 29.1954 & 389 & الاجمالى & \\
\hline \multirow{3}{*}{$\begin{array}{l}0.704 \\
\text { غير دالة }\end{array}$} & \multirow{3}{*}{-.380} & 2.21815 & 10.2969 & 229 & ذكر & \multirow{3}{*}{ التعامل مجمع الطلاب } \\
\hline & & 2.06154 & 10.3813 & 160 & انثى & \\
\hline & & 2.15281 & 10.3316 & 389 & الاجمالى & \\
\hline \multirow{3}{*}{ غير دالة 0.123} & \multirow{3}{*}{-1.548} & 1.66816 & 8.0480 & 229 & ذكر & \multirow{3}{*}{ الهادة العلمية محور } \\
\hline & & 1.44414 & 8.3000 & 160 & انثى & \\
\hline & & 1.58281 & 8.1517 & 389 & الاجمالى & \\
\hline \multirow{3}{*}{ غير دالة } & \multirow{3}{*}{-.502} & 3.56399 & 18.4279 & 229 & ذكر & \multirow{3}{*}{ مجموع محور } \\
\hline & & 3.27194 & 18.6063 & 160 & انثى & \\
\hline & & 3.44367 & 18.5013 & 389 & الاجمالى & \\
\hline \multirow{3}{*}{ غير دالة } & \multirow{3}{*}{-1.489} & 2.25227 & 10.1223 & 229 & ذكر & \multirow{3}{*}{ المعايير مهنية محور } \\
\hline & & 1.84543 & 10.4438 & 160 & انثى & \\
\hline & & 2.09799 & 10.2545 & 389 & الاجمالى & \\
\hline
\end{tabular}

يتضح من الجدول عدم وجود فروق دالة إحصائياً عند مسنوى معنوية (0.

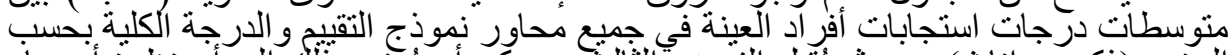

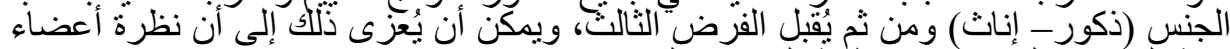

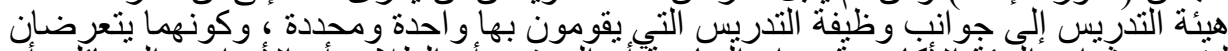

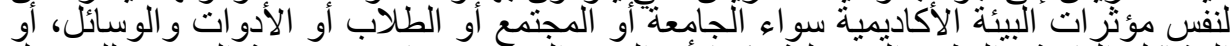

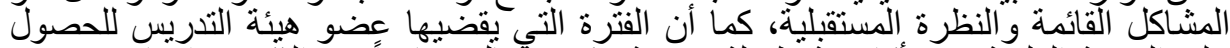

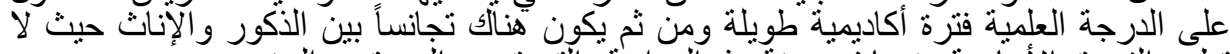
تظهي الفروق إلأسأسية بينهما في عينة هذه الدراسة استة والتي ترجع إلى متغير الجنس.

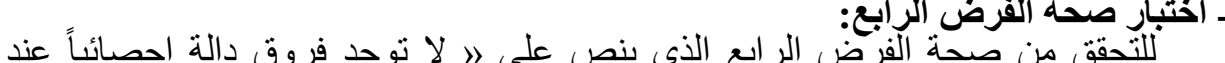

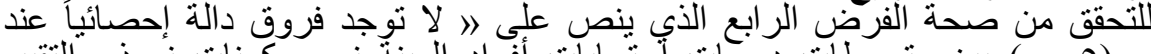

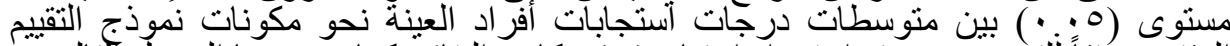

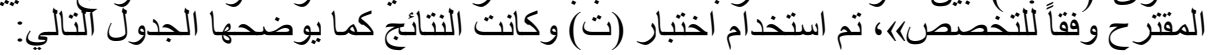

جدول (0) دلالة الفروق بين متوسطات درجات استجابات أفراد العينةبحسب متغير التخصص

\begin{tabular}{|c|c|c|c|c|c|c|}
\hline الإحصائية & قتهة & اللانحرافي & الهتوسط & $\mathrm{N}$ & التخصص & المحاور \\
\hline \multirow{3}{*}{$\begin{array}{c}0.001 \\
\text { دالة }\end{array}$} & \multirow{3}{*}{-4.441} & 17.97684 & 105.4107 & 224 & نظري & \multirow{3}{*}{ مجموع ملف الإنجاز } \\
\hline & & 8.29283 & 112.0970 & 165 & عملى & \\
\hline & & 15.02509 & 108.2468 & 389 & الاحمبار & \\
\hline
\end{tabular}


مجلة الاقتصاد المنزلي، مجلد بr ـ العدد الأول ـ r ب ץ

\begin{tabular}{|c|c|c|c|c|c|c|}
\hline \multirow{3}{*}{$\begin{array}{l}0.001 \\
\text { دالة }\end{array}$} & \multirow{3}{*}{-4.865} & 37.38707 & 199.5223 & 224 & نظري & \multirow{3}{*}{ مجموع الاستبانة } \\
\hline & & 14.66435 & 214.4667 & 165 & عملى & \\
\hline & & 30.80511 & 205.8612 & 389 & الاجمالي & \\
\hline \multirow{3}{*}{$\begin{array}{c}0.004 \\
\text { دالة }\end{array}$} & \multirow{3}{*}{-2.928} & 2.24919 & 16.3125 & 224 & نظري & \multirow{3}{*}{ مجموع البيانات العامة } \\
\hline & & 1.43401 & 16.8970 & 165 & عملى & \\
\hline & & 1.96479 & 16.5604 & 389 & الاجمالي & \\
\hline \multirow{3}{*}{$\begin{array}{ll}0.006 \\
0\end{array}$} & \multirow{3}{*}{-2.746} & 3.99054 & 23.6473 & 224 & نظري & \multirow{3}{*}{ مجموع محور } \\
\hline & & 2.59303 & 24.6242 & 165 & عملى & \\
\hline & & 3.49688 & 24.0617 & 389 & الاجمالى & \\
\hline \multirow{3}{*}{$\begin{array}{l}0.001 \\
\text { دالة }\end{array}$} & \multirow{3}{*}{-4.474} & 6.82390 & 33.7098 & 224 & نظري & \multirow{3}{*}{ البحث العلمي } \\
\hline & & 3.31075 & 36.2848 & 165 & عملى & \\
\hline & & 5.74630 & 34.8021 & 389 & الاجمالي ل الي & \\
\hline \multirow{3}{*}{$\begin{array}{ll}0.001 \\
\text { دالة }\end{array}$} & \multirow{3}{*}{-5.347} & 5.78035 & 31.7411 & 224 & نظري & \multirow{3}{*}{ خدمة الجامعة والهجتهع } \\
\hline & & 2.35563 & 34.2909 & 165 & عملى & \\
\hline & & 4.81052 & 32.8226 & 389 & الاجمالي & \\
\hline \multirow{3}{*}{$\begin{array}{l}0.001 \\
\text { دالة }\end{array}$} & \multirow{3}{*}{-4.628} & 1.65872 & 7.6696 & 224 & نظري & \multirow{3}{*}{ مخرجات ونواتج التعلم } \\
\hline & & .93269 & 8.3333 & 165 & عملى & \\
\hline & & 1.43418 & 7.9512 & 389 & الاجمالي & \\
\hline \multirow{3}{*}{$\begin{array}{l}0.001 \\
0.00\end{array}$} & \multirow{3}{*}{-4.223} & 2.88671 & 12.7813 & 224 & نظري & \multirow{3}{*}{ طرق التدريس محور } \\
\hline & & 1.63159 & 13.8364 & 165 & عملى & \\
\hline & & 2.48741 & 13.2288 & 389 & الاجمالى & \\
\hline \multirow{3}{*}{$\begin{array}{ll}0.001 \\
\text { دالة }\end{array}$} & \multirow{3}{*}{-4.314} & 5.83685 & 28.3036 & 224 & نظري - ن ن ن & \multirow{3}{*}{ بيئة التعلم محور } \\
\hline & & 2.63396 & 30.4061 & 165 & عملى & \\
\hline & & 4.85755 & 29.1954 & 389 & الاجمالى & \\
\hline \multirow{3}{*}{$\begin{array}{ll}0.001 \\
\text { دالة }\end{array}$} & \multirow{3}{*}{-3.694} & 2.54113 & 9.9911 & 224 & نظري & \multirow{3}{*}{ التعامل مع الطلاب } \\
\hline & & 1.34571 & 10.7939 & 165 & عملى & \\
\hline & & 2.15281 & 10.3316 & 389 & 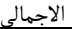 & \\
\hline \multirow{3}{*}{$\begin{array}{ll}0.001 \\
\text { دالة }\end{array}$} & & 1.90581 & 7.7991 & 224 & نظري & \\
\hline & -5.294 & .76688 & 8.6303 & 165 & عملى & مجموع محور \\
\hline & & 1.58281 & 8.1517 & 389 & الاجمالى & \\
\hline 0001 & & 3.99676 & 17.8393 & 224 & نظري & \\
\hline مالة & -4.527 & 2.21910 & 19.4000 & 165 & عملى & مجموع محور التقييم \\
\hline & & 3.44367 & 18.5013 & 389 & الاجمالى & \\
\hline & & 2.47171 & 9.7277 & 224 & نظري & \\
\hline إلة & -6.028 & 1.10113 & 10.9697 & 165 & عملى & مجموع محور \\
\hline & & 2.09799 & 10.2545 & 389 & الاجمالي & \\
\hline
\end{tabular}

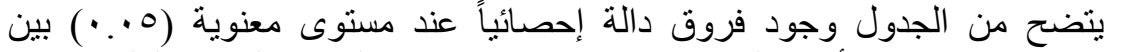

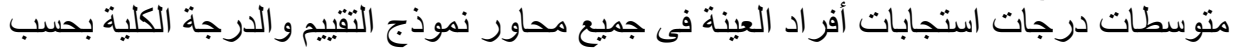

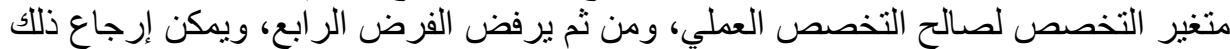

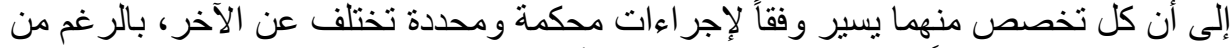

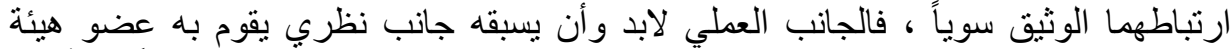

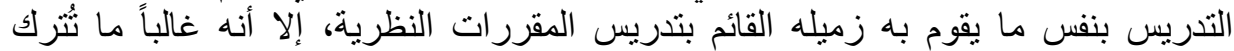
الجو انب العملية لعمل الطالب نفسه.

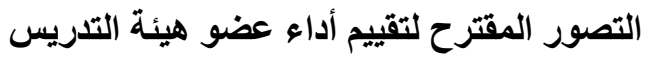

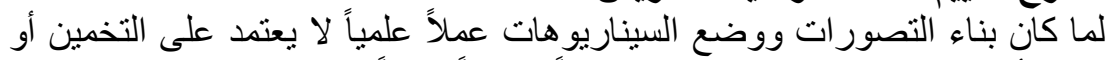

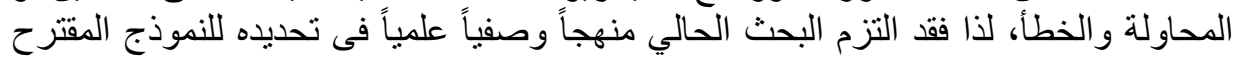
لتقييم أداء عضو هيئة التدريس بالجامعات المصرية، و فيما يلي توضيح لذلك: 


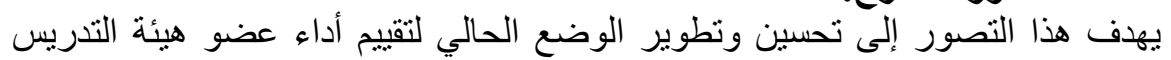

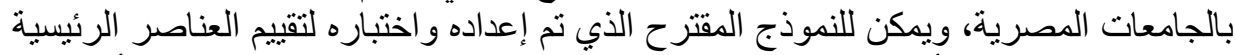

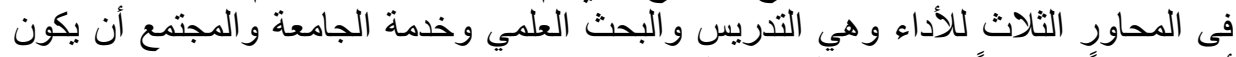

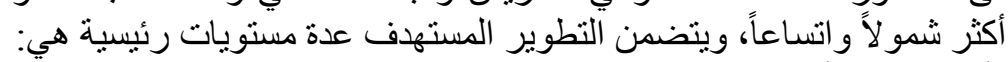

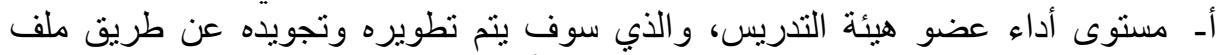

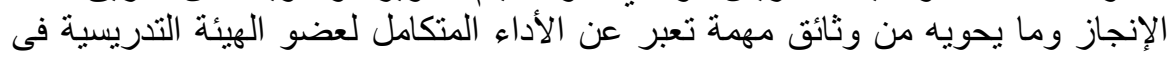

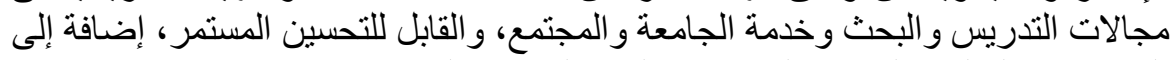

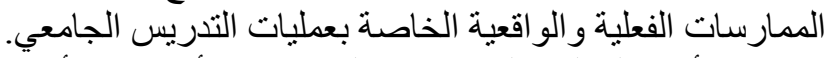

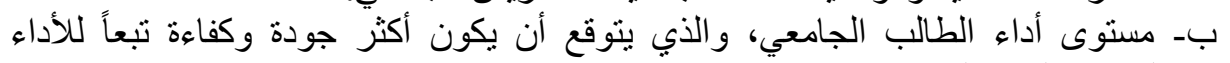

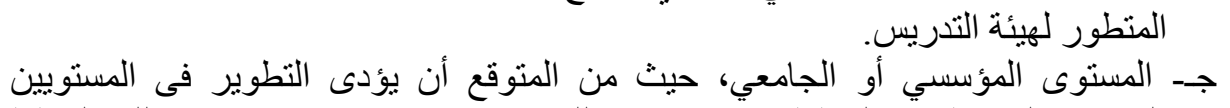

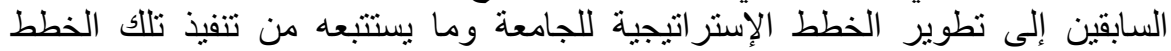

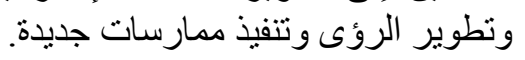

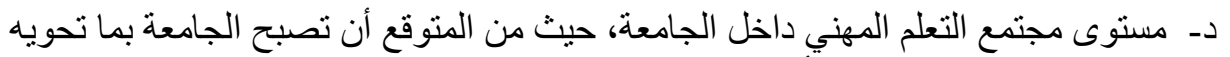

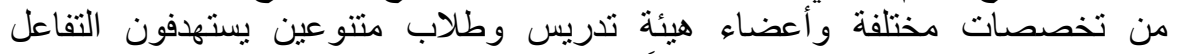

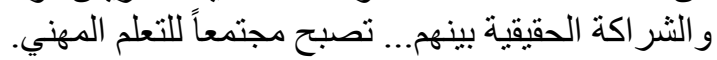

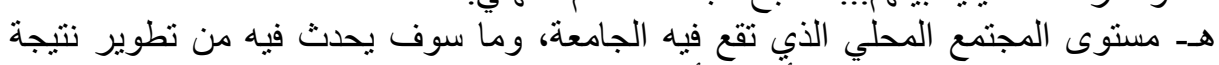

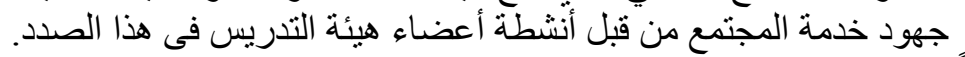

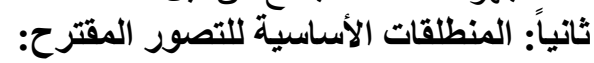

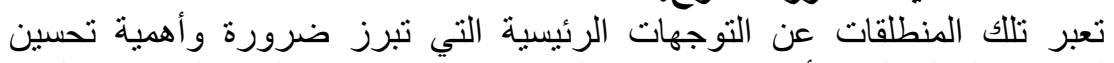

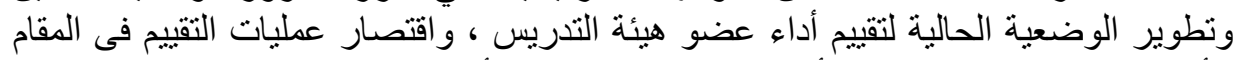

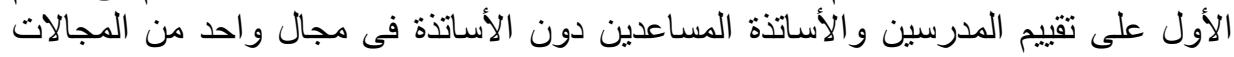

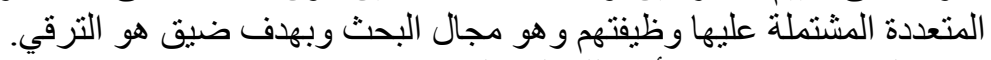

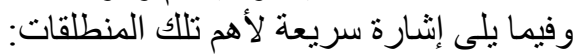

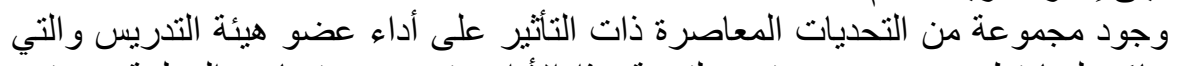

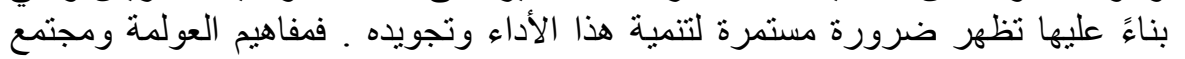

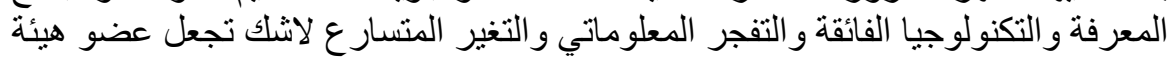

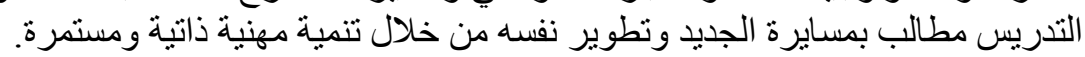

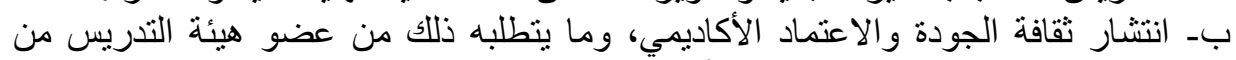

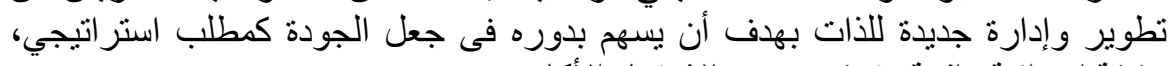

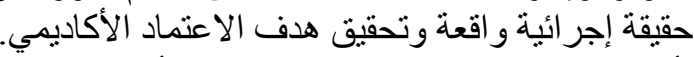

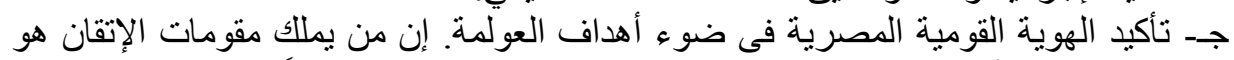

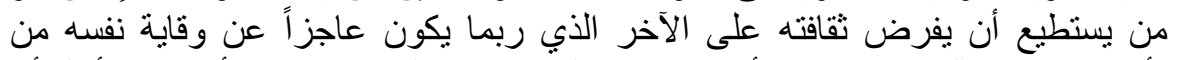

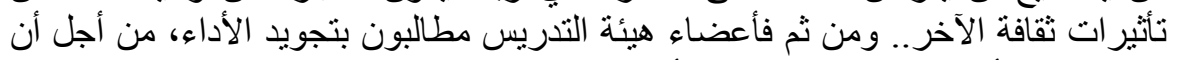

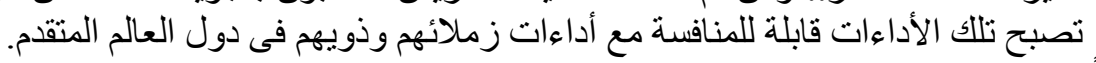
ثالثاً: مسلمات التصور المقترح: 


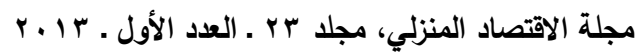

يتضمن التصور المقترح جملة من المسلمات يمكن حصر أهمها فيما يلي: أـ تقييم أداء عضور هيئة التدريس يعد ضرن الترورة.

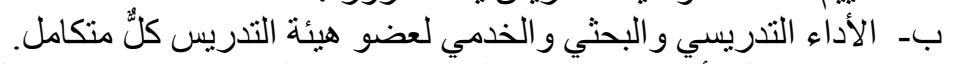

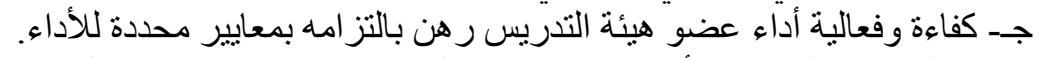

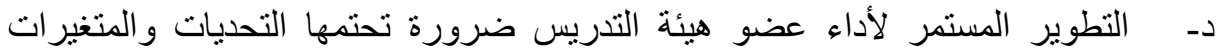

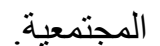

هـــ التأثير المبانشر لأداء عضو هيئة التدريس على مخرجات التعليم الجامعي.

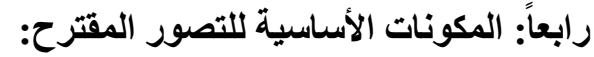

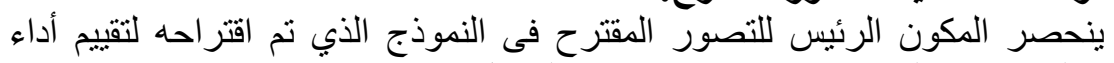

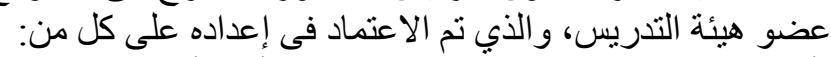

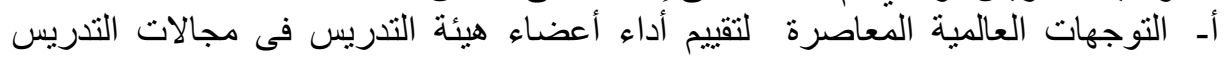

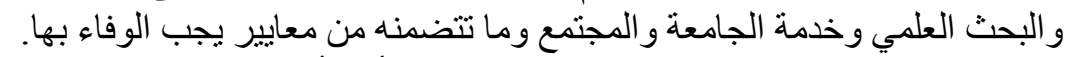

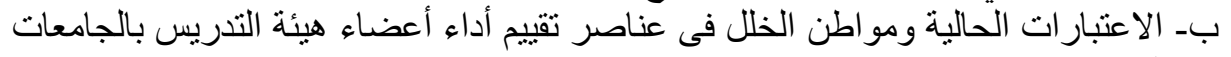

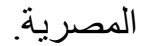
ج- استمارة استقصاء آراء أعضاء هيئة التندريس و الخبر اء في معايير التقييم المقترحة.

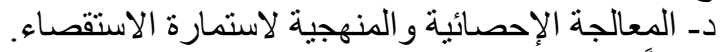

خامساً: آليات تثفيذ التصور المقترح:

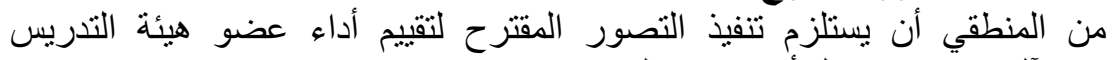

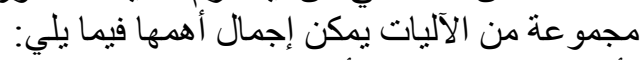

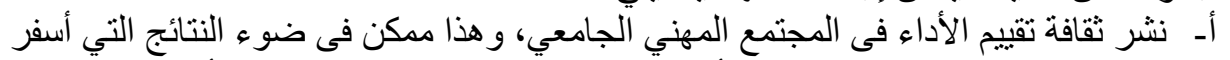

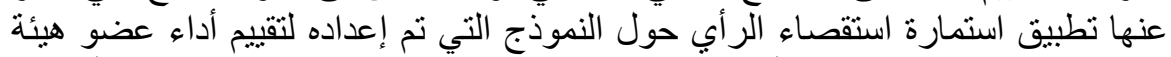

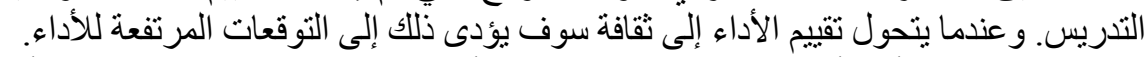

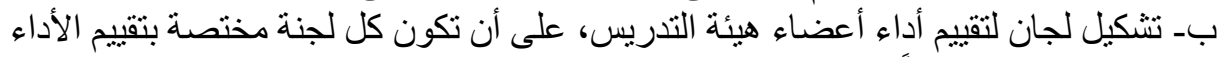

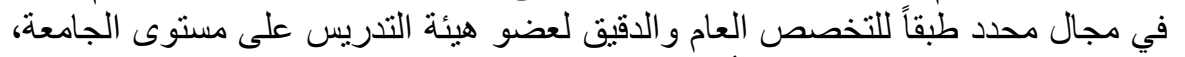

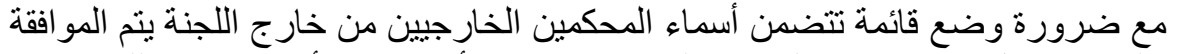

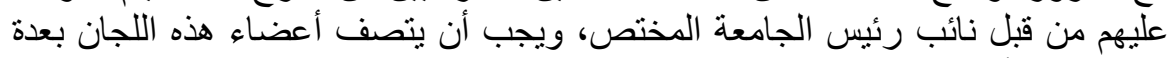
صفات، من أهمها:ـ التخصص الدقيق فى نفس المجال الذي ينسق مع تخصص عضو هيئة التدريس.

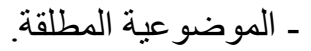
ـ الدر اية الكاملة بالمحكات و المعلة المعايير المتضمنة و الواردة داخل نموذج تقييم الأداء.

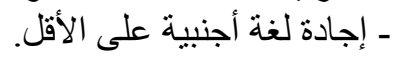

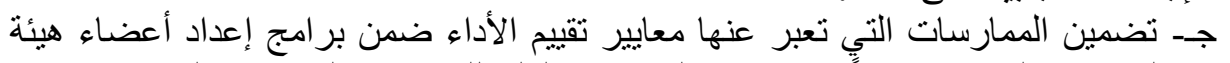

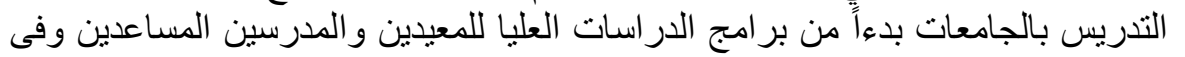

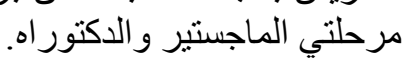

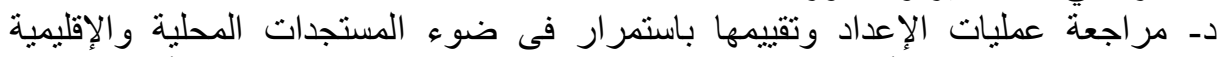

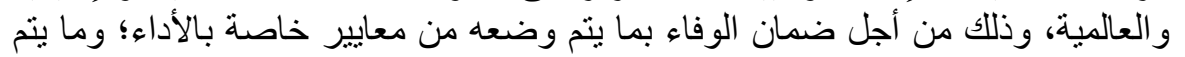
تطويره منها. 


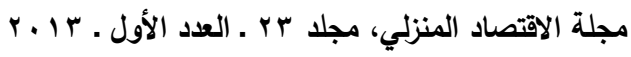

هـ توفير بر امج التتمية المهنية المستمرة للهيئة المعاونة و أعضاء هيئة التدريس فى الجامعات من أجل منابعة الجديد.

و - ضرورة الاهتمام بجودة الأبحاث وليس عددها، وجعل البحوث الخاصة بالأداء وتقييم

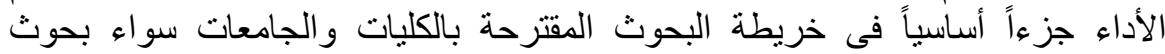
الماجستير والدكتور اه أو بحوث ألعاء أعضاء هيئة التدريس.

زـ تطوير اللوائح والتشريعات التي تسمح بنطبيق واختبار وتطوير النموذج المقترح حين بلزم الأمر. حــ نوفير التمويل اللازم باعتباره أحد الآليات المهمة والحاكمة لتنفيذ النموذج المقتر ح.

سادساً: متطلبات تنفيذ التصور المقترح:

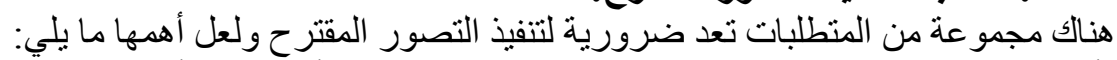

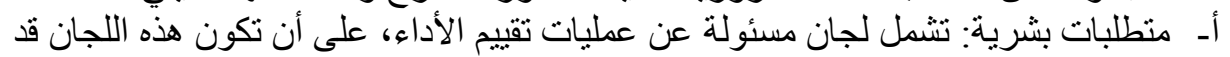

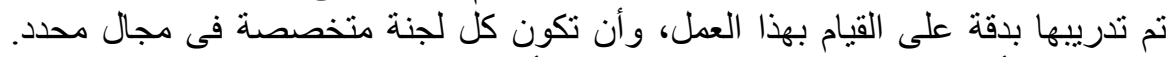

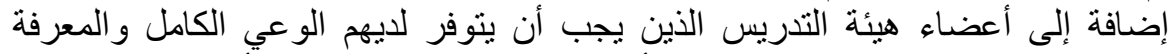

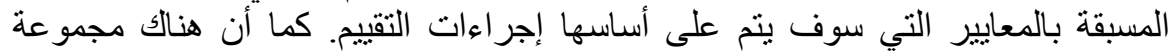

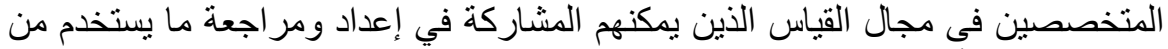
مقاييس لتقبيم الأداء.

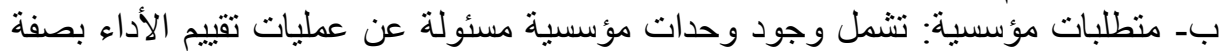

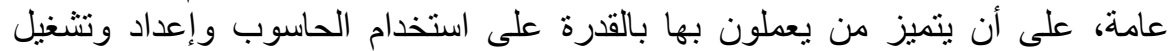

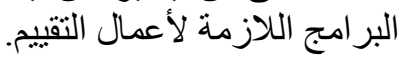
ج- منطلبات مادية: يشمل ذللك توفير الأجهزة و البرامج وكليم وكل ما تتطلبه عمليات التقييم.

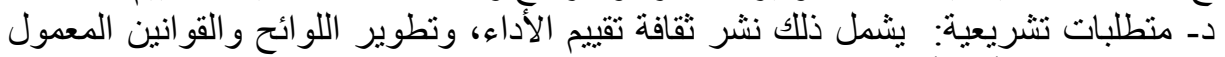

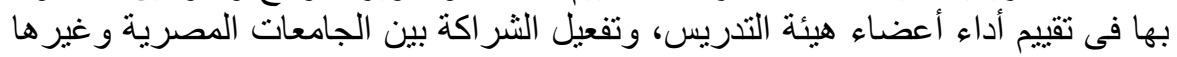
من الجامعات العربية و العالمية. هــ توفير بيئة داعمة داخل الجامعات المصرية.

والثكل التالي يوضح التصور المقترح: 
مجلة الاقتصاد المنزبي، مجلد بr ـ العدد الأول ـ r r r r

تصور مفترح لتقييم أداء عضو هيئة التتريس بالجامعات المصرية

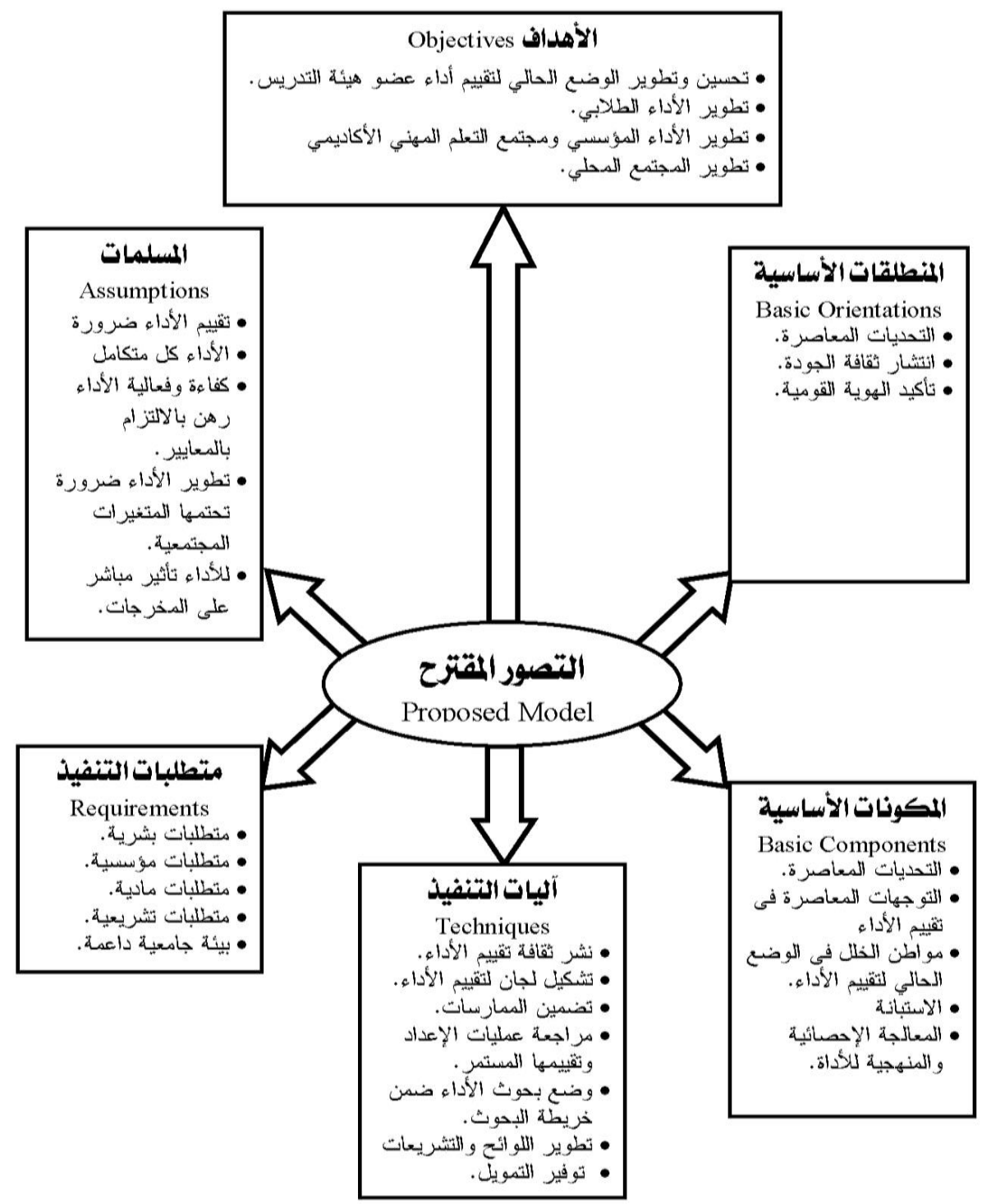




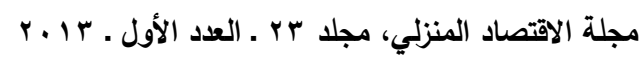

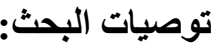

فى ضو ضو ه نتائج البحث البحث تقدم التوصيات التالية:

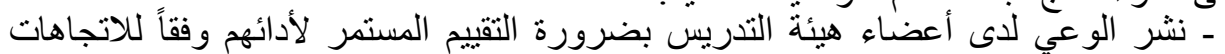

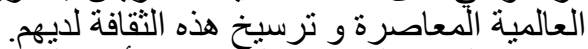

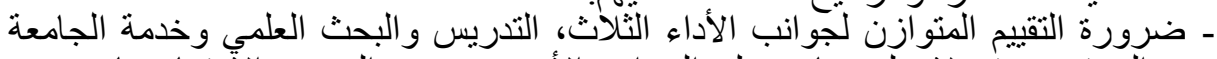

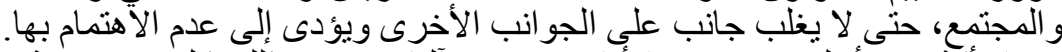

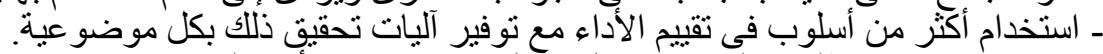

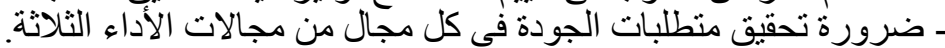

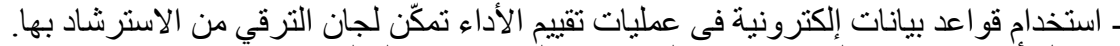
ـ تبادل أعضاء هيئة التذريس بين الجامعات المئرونية فئية المصرية و العالمية.

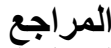

ابتسام إبر اهيم الحديثي (V . . . Y): الإنتاجية العلمية لأعضاء هيئة التدريس السعوديات بكليات التربية للبنات بالمملكة العربية السعودية الإنية ــ در استة تقويمية، لاعية رسالة ماجستير، كلية التربية،

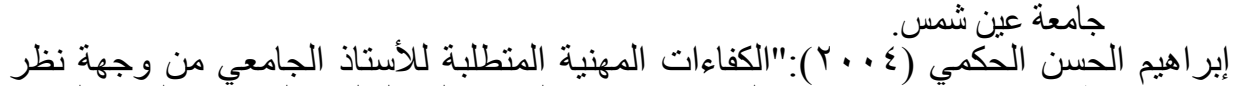

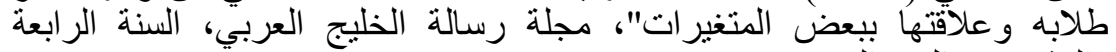

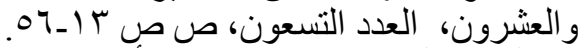

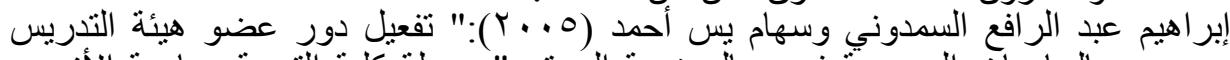

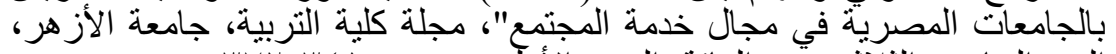

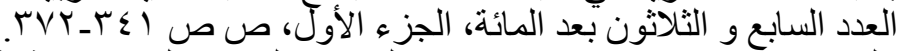

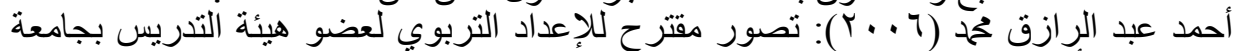

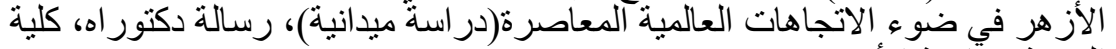

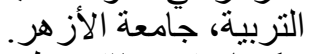

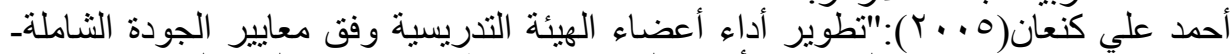

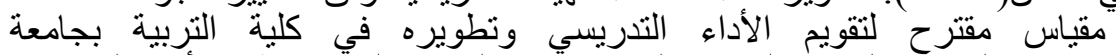

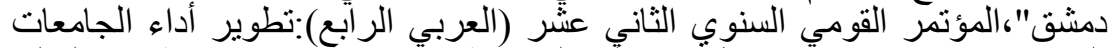

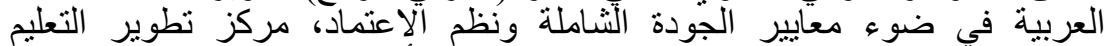

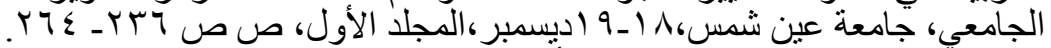

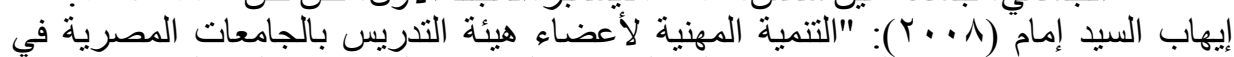

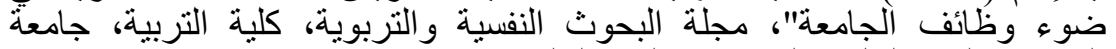

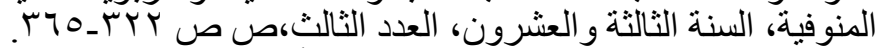

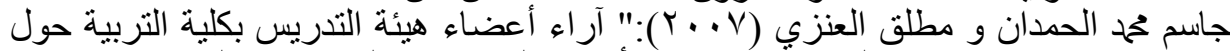

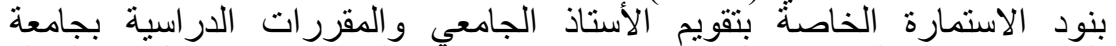

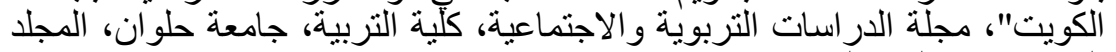

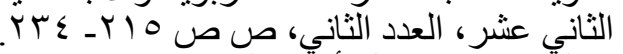

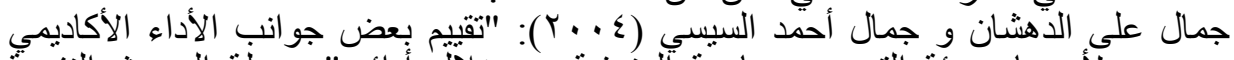

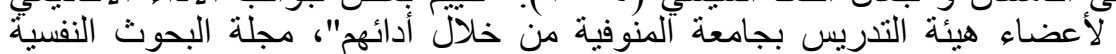

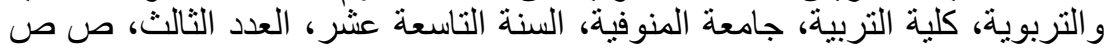
I Y . - O

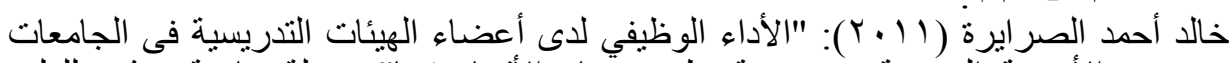

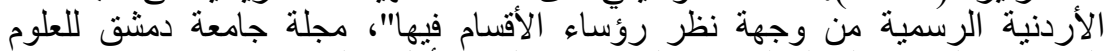

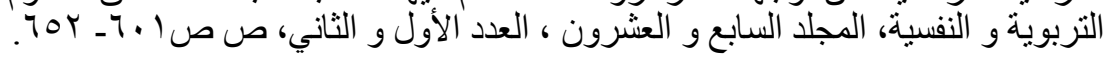




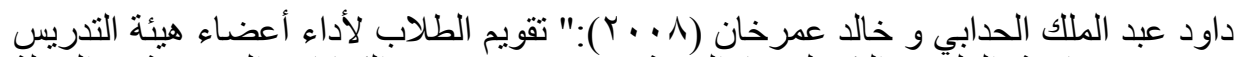

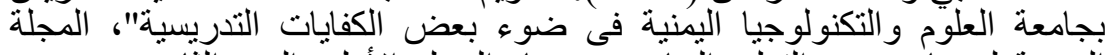

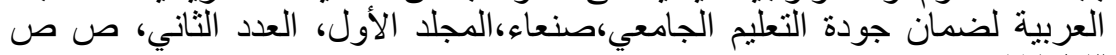
.V $V \leqslant-74$

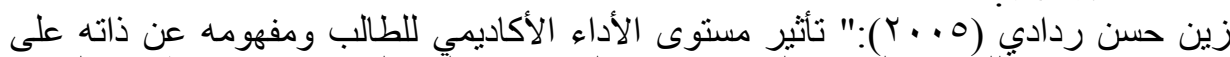

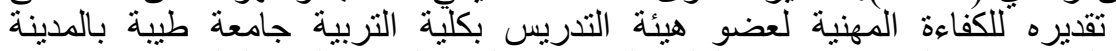

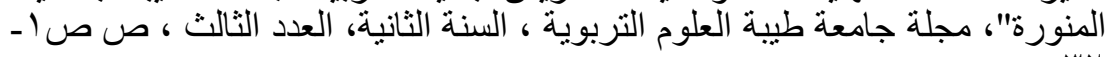

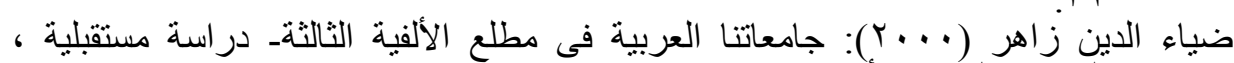
القاهرة، المكتبة الأكاديمية.

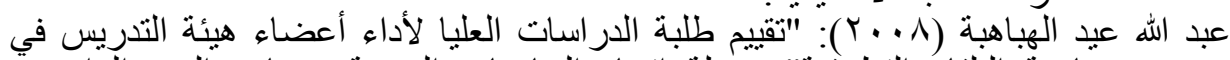

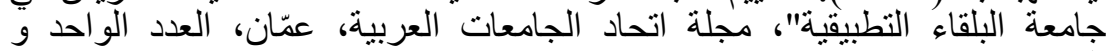

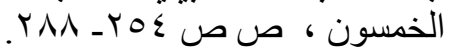

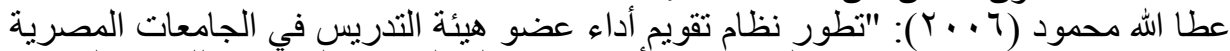

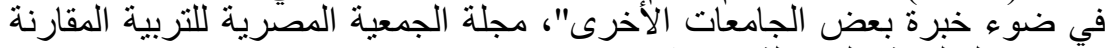

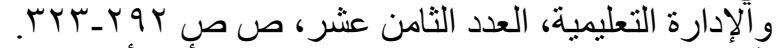

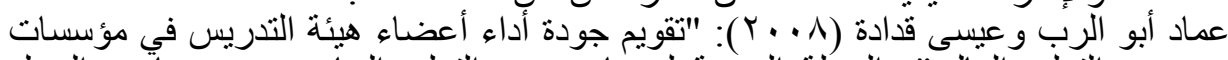

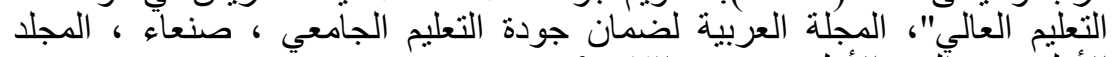

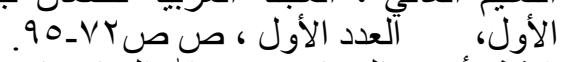

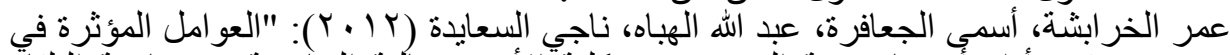

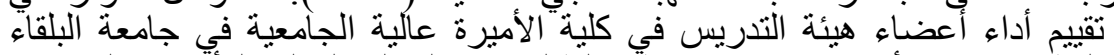

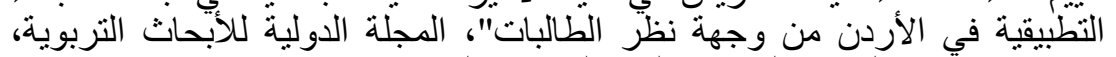

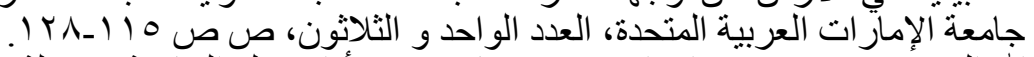

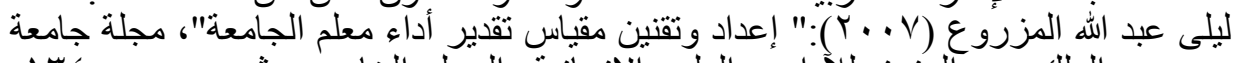

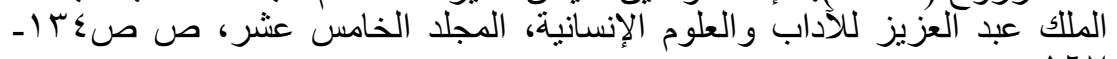
IV

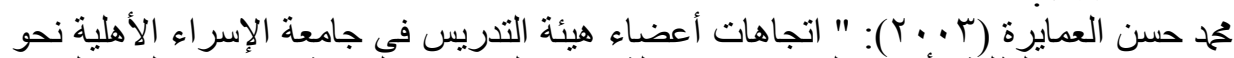

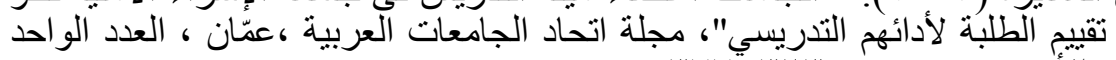

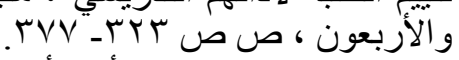

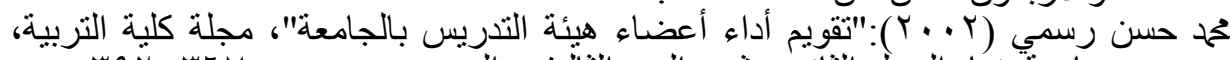

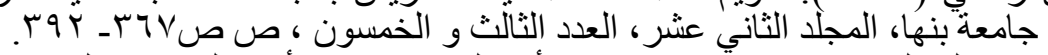

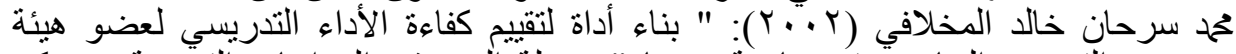

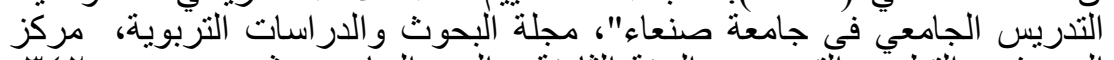

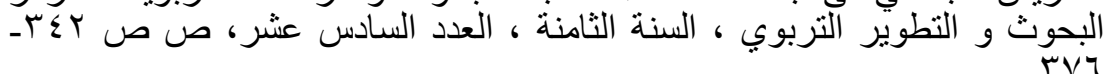

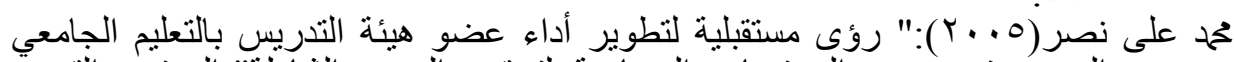

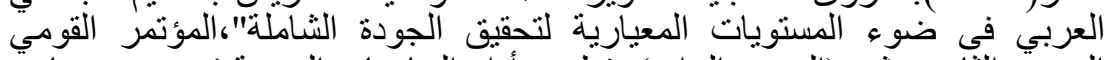

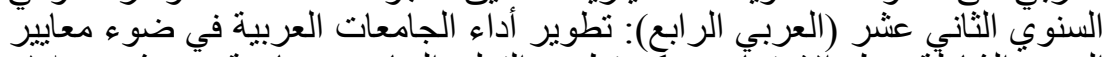

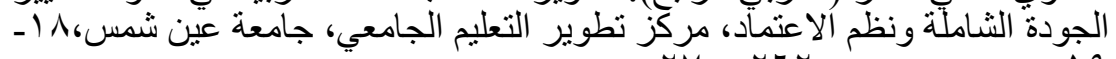

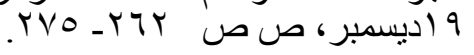




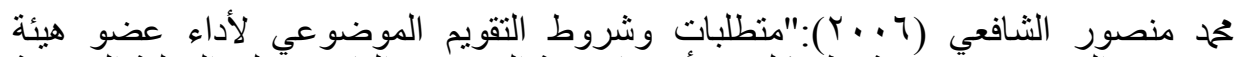

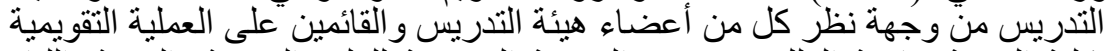

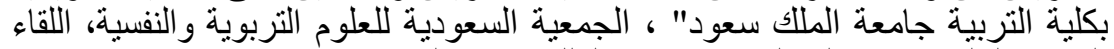

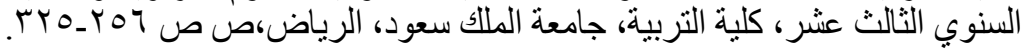

\section{Available at : www.gesten.org.sa}

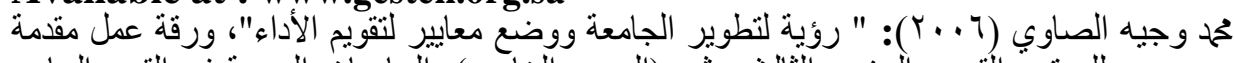

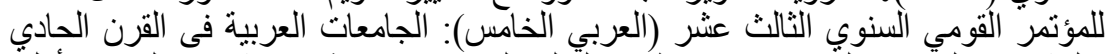

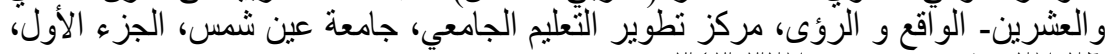
د د د

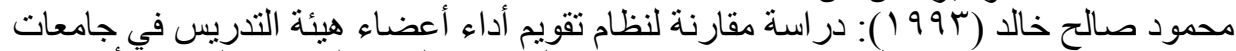

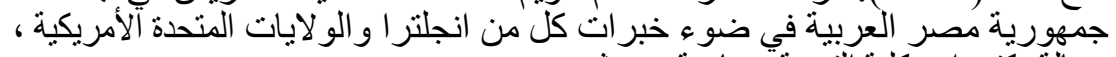

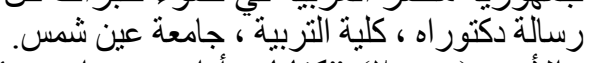

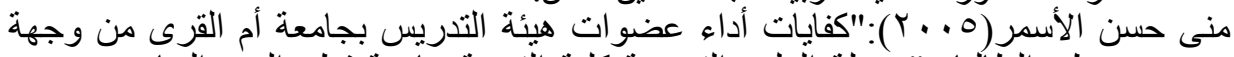

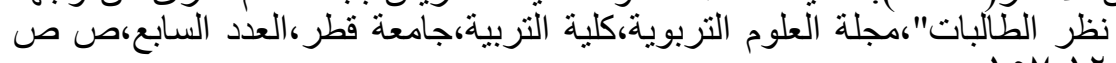
loV-lt

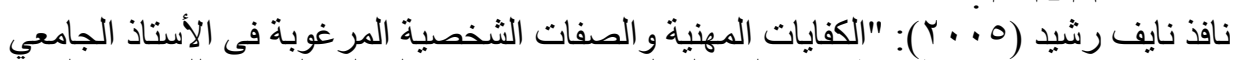

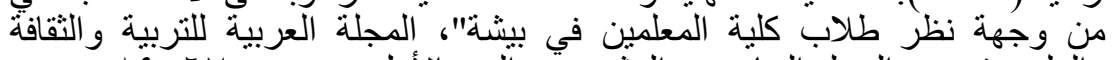

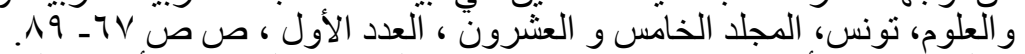

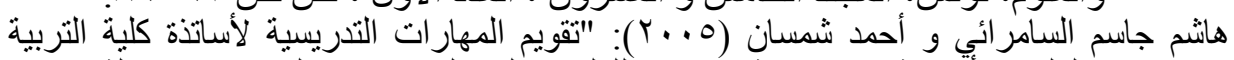

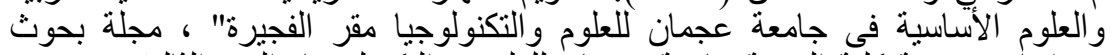

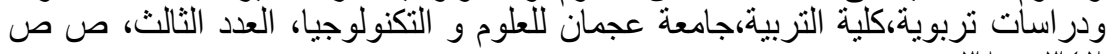

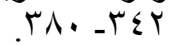

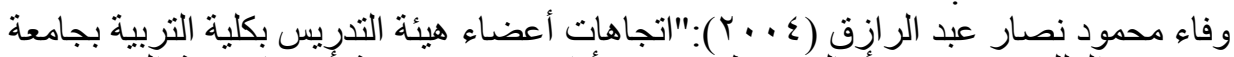

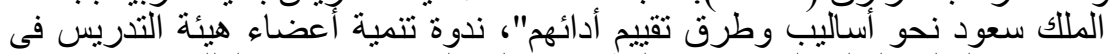

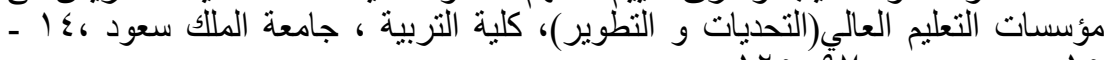

Available at: http://education.ksu.edu.sa/

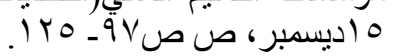

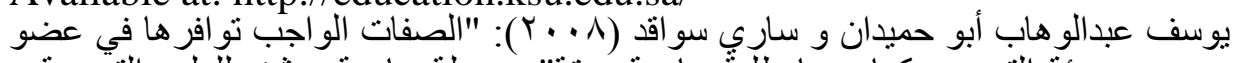

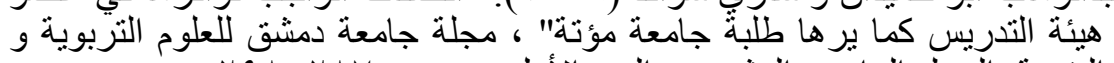

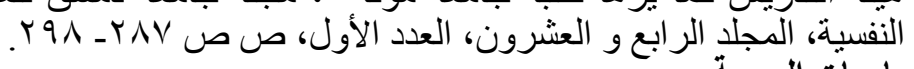
مراجع الجامعاث العربية:

نظام مجلس التعليم العالي و الجامعات ولو ائحه (9 . . ب): المملكة العربية السعودية، جامعة

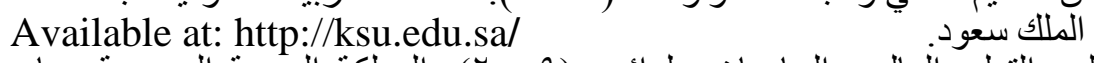

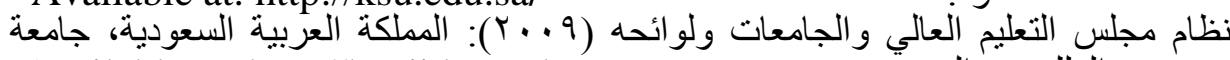
Available at: http://hnaji.kau.edu.sa الملك عبد العزيز.

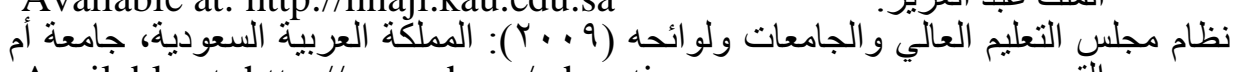

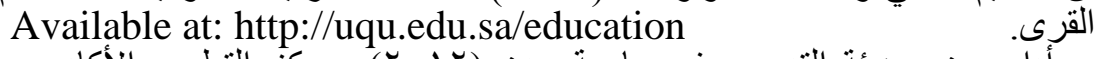
لائحة تقويم أداء عضية اليمنية.

Available at: Http://Uniaden-Adc.Com/Evaluating_Faculty.Htm

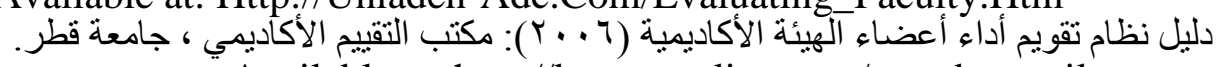
Available at: http://kenanaonline.com/sayed-esmail 


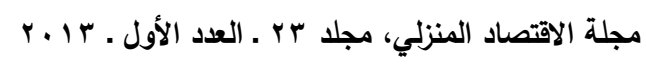

وثيقة تفسيرية تعليمية للإطار المفاهيمي لكلية التربية (r . . ץ): كلية التربية، جامعة الإمارات

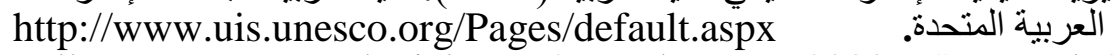

Ballantyne, R., Barthwick, J. \& Packer, J. (2000): "Beyond Student Evaluation of Teaching: Identifying and Addressing Academic Staff Development Needs", Assessment and Evaluation in Higher Education, Vol. 3, pp. 221-225.

Bepko, G. L. (2002):" Full Services Schools: Involving the Urban University in School Improvement and Community Redevelopment", Metropolitan Universities, B (4), pp. 72-87.

Best, J. B. \& Addison, W. E. (2000): "Preliminary Study of Perceived Warmth of Professor and Student Evaluations", Teaching Psychology, Vol. 27, pp. 60-62.

Gage, N. L. (2004): " The Appraisal of College. Teaching Journal of Higher Education", Vol. 28, pp.17-22.

Harrison, E. J. (2002): The Quality of University Teaching: Faculty Performance and Accountability, A Literature Review, Professional File, Spring, ERIC. ED. NO. 474377.

Hawthome, E. M. (2000): "A Fuse on University Faculty Service to Community Colleges", Community College Review, 19 (1), pp. 30-35.

Holland, B. A. (2001): "A Comprehensive Model for Assessing Service, Learning and Community, University Partnerships", New Directions for Higher Education, No. 114, pp. 51-60.

Kerlinger, F. (2003):"Student Evaluation of Faculty Grading Methods", Journal of Education for Business, Vol. 78, July, p. 88-100.

Marguerite, G. and Others (2006): Methods in Educational Research: from Theory to Practice, New York, John Wiley \& Sons, Inc.

Marsh, H. W. (2001): "Student's Evaluations of University Teaching: Research Findings, Methodological Issues and Directions for Future Research", International Journal of Educational Research, Vol. 19, pp.440-450.

Millcy, W.M. (2003): "What You Don't Know Can Hurt You? Teaching Habits", College Students Journal, 37 (3), pp. 127-170.

Pozo, M. C., Rebollose, P. E. and Fernandez R. B.(2000):" "Ideal Teacher" Implication for Student Evaluation of Teacher Effectiveness", Assessment and Evaluation in Higher Education ,Vol. 25, pp. 253- 256.

Sapp, A. (2002): "Critical Thinking, Community Service and Participatory Research: Restructuring the American University for a Framework of Learning", Michigan Journal of Community Service Learning, 7 (4), pp. 109-130.

Seldin, P. A. (1998): "Evaluating College Teaching", New Directions for Teaching and Learning, No. 33, pp. 98-112. 


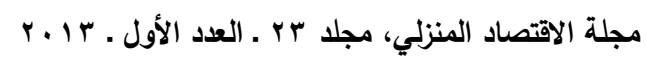

Seldin, P. A. (1999): Changing Practices in Faculty Evaluation, San Francisco, Jossey- Bass Publishers.

Shevlin, M., Banyard, P., Davies M. \& Griffiths M. (2000): "The Validity of Student Evaluation of Teaching in Higher Education", Assessment and Evaluation in Higher Education, Vol. 4, pp. 397- 400.

Simon, C. (2003): "An Alternative Method to Measure MIS Faculty Teaching Performance", The International Journal of Educational Management, 17 (5), pp. 195-199.

Vaughn, J. (2002): "Accreditation, Commercial Rankings and New Approaches to Assessing the Quality of University Research and Educational Programs in the United States", Higher Education in Europe, 27 (4), pp. 433-461.

Indiana University Southeast: Available at: http://www.ius.edu/

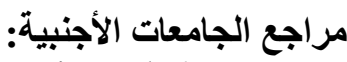

University of Central Florida (2006): Faculty Performance Assessment Plan. Available at: http://www.fctl.ucf.edu/careertrack/documents /accounting.pdf

The University of Marshall (2010): Manual for Faculty Evaluation Available http://www.marshall.edu/coe/administration/forms/pdf/Handboo k.pdf

The University of Liverpool (2011): Staff Development, A Draft Scheme of Staff. Development and Appraisal for Academic and Academic Related Staff . Available at http://www.liv.ac.uk/

The University of the State of New York (2005): The State Education Department Handbook of Institutional Accreditation. Available at: www.highered.nysed.gov/ocue/accred/intro.htm.

Kennesaw State University (2009) : Evaluation Handbook University Publications. Available at: http://www.kennesaw.edu/ 


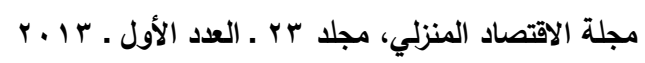

\begin{abstract}
:
This research was an attempt to construct a valid and reliable model toassess faculty performance in Egyptian universities using the descriptive survey method. Attempt was also made to examine such model through applying it to a sample of 384 faculty member from different universities and specialties. The study explored the current status of assessing Egyptian faculty performance, the major contemporary international trends in assessing faculty performance, and construct a proposed model of assessing faculty performance. The prospected model composed mainly of two parts: the portfolio and the questionnaire. The model composed of seven elements: Goals, foundations, assumptions, components, means, requirements and obstacles. This model is expected to be beneficial to the university higher education and the future directions of the performance assessment movement.
\end{abstract}

